\title{
Changes of Technosol properties and vegetation structure along a chronosequence of dredged sediment deposition in areas with alluvial gold mining in Colombia
}

\author{
Bibiana Betancur-Corredor $^{1,2}$ (D) Juan Carlos Loaiza-Usuga ${ }^{3} \cdot$ Manfred Denich $^{1} \cdot$ Christian Borgemeister $^{1}$
}

Received: 5 November 2018 / Accepted: 20 December 2019/Published online: 14 March 2020

(C) The Author(s) 2020

\begin{abstract}
Purpose Alluvial gold mining leaves a vast amount of dredged sediment that covers the natural soil, destroys riparian ecosystems, and impacts riverbeds and valleys. In Colombia, more than 80,000 ha are covered by dredged sediment. Technosols developed from such deposits undergo strong transformations during the early stages of formation due to the diverse nature of the constituents. The aims of this study are (i) to investigate changes in soil morphological and physicochemical properties at early stages of pedogenesis, (ii) to estimate the variability of size structure distribution of the new plant cover as affected by the time period since establishment and deposit type, and (iii) to determine which soil parameters correlate best with the size structure distribution of vegetation.

Materials and methods Soil characterization through morphological and physicochemical analysis was conducted on Technosols developed from gravel and sandy deposits of different ages ( $0-12$ years). A vegetation survey was conducted to measure tree dimensions and identify the most common species. Data were analyzed using non-parametric tests to avoid the loss of information due to data smoothing.

Results and discussion The studied Technosols are subject to processes similar to those occurring in natural parent materials such as mineral transformations, changes in redox conditions, organic matter accumulation in the topsoil, and a rapid differentiation of horizons. However, the Technosols in our study sites show an unusually fast development not often observed in natural soils, with drastic changes observed at very early stages of formation. Gravel deposits offer more favorable conditions for plant growth, and marked changes in pedogenic processes can be observed compared with sandy deposits, which are reflected in changes of chemical properties.

Conclusions Factors such as the technology used for mining and the continuous deposition of dredged sediments in a cumulative way during the exploitation period, as well as the disturbances after deposition, result in a high diversity of constituents and high heterogeneity of dredged sediment deposits. Gravel and sand deposits, originated from the same sections of the river and after similar separation processes for ore extraction, undergo divergent pedogenic processes at different rates, which could be explained by a remarkable effect of particle size distribution. For vegetation establishment, the selection of tree species should be based on their capacity for nutrient pumping through deep rooting to sequester carbon and to adapt morphologically to heterogeneity in nutrient availability by growing roots in nutrient-rich zones.
\end{abstract}

Responsible editor: Rongliang Qiu

Bibiana Betancur-Corredor

bibetaco@gmail.com

1 Center for Development Research (ZEF), University of Bonn, Genscherallee 3, 53113 Bonn, Germany

2 Present address: Senckenberg Museum of Natural History, Am Museum 1, Görlitz 02828, Germany

3 Departamento de Geociencias y Medio Ambiente, Facultad de Minas, Colombia Universidad Nacional de Colombia, Cl. 80 \#65, 223, Antioquia Medellín, Colombia
Keywords Pedogenic trends - Post-mining land use · Technogenic materials · Vegetation size structure · Variability and heterogeneity

\section{Introduction}

Alluvial gold mining, particularly dredging operations, leaves a vast amount of dredged sediment that covers the natural soil, destroys riparian ecosystems, and impacts riverbeds and valleys (Shlyakhov and Osipov 2004). According to the latest report published by the Colombian environmental authority 
in 2016, an area of 78,939 ha had been affected by alluvial gold mining by 2014 (UNODC 2016). In addition, 24,450 ha of natural forest and secondary vegetation were lost in 2014 due to alluvial gold mining activities. An analysis of the temporal dynamics shows that between 2001 and 2014, an area of 44,746 ha was degraded by alluvial gold mining over the whole country (UNODC 2016). Once the exploitation of alluvial deposits using suction and bucket dredges has taken place, the dredges are transferred to a new working front leaving behind three elements: (i) gravel deposits that consist of rock fragments coming from material extracted by bucket dredges, (ii) sandy deposits that consist of sand from material extracted by suction dredges, and (iii) artificial wetlands that remain after the exploitation of the deep alluvium of the river and surrounding swamps. Deposits created by alluvial gold mining usually have a low macronutrient content and an acidic $\mathrm{pH}$ that tend to disrupt soil-forming processes and plant growth (Cooke and Johnson 2002). There is also a discontinuity between the upper and lower parts of the soil profiles due to the superimposition of the dredged sediment over the natural soil (Wahsha and Al-Rshaidat 2014).

The dredged sediment deposits formed after alluvial exploitation are the parent material of soils which can be classified as Technosols given the human influence exerted on them and the fact that their properties and pedogenesis are dominated by their technical origin (IUSS Working Group WRB 2015). Soils that are the result of a combination of materials, such as the materials deposited by dredges, undergo strong transformations during the early stages of formation. Even if the composition of Technosols is in principle different to the composition of natural soils, their pedogenesis is controlled by the effect of aggregation or decarbonisation factors, i.e., soil fauna, microorganisms, plant roots, binding agents, and environmental conditions which may be similar to those in natural soils (Jangorzo et al. 2013). However, technogenic materials often display highly diverse constituents, high spatial variability, and frequently reported more intense and rapid pedogenic processes in the first stages of weathering than in natural soils (Huot et al. 2015), possibly due to imbalances between soil artifacts (IUSS Working Group WRB 2015) and environmental conditions (Séré et al. 2010).

Technogenic materials changed by soil-forming processes may create (i) a high diversity of constituents and the potential for simultaneous occurrence of processes that would have taken place in contrasting climatic conditions, (ii) high spatial variability of the materials and changes in topography resulting from localized processes, anthropogenic influence, or distinct rates of soil development over short distances, and (iii) successive and simultaneous processes occurring at different time scales (Huot et al. 2015). Therefore, it is important to analyze the degree of advanced soil-forming processes in Technosols over periods of time based on the analysis of soil morphological properties and conventional measurements of soil physicochemical properties that are the result of successional changes in the vegetation cover.

One approach to characterize transformations of Technosols typically involves the identification of a chronosequence consisting of sampling and measurements in recently deposited materials and contrasting the results with those of Technosols developed a long time ago. Yet, Technosols are very heterogeneous, and the properties of each area of the deposits depend on the technology used for gold mining or the intensity of weathering processes. Therefore, transformation processes have to be interpreted with care (Uzarowicz et al. 2017). Furthermore, comparing plant community resemblance between different sites or the progressive change over time can provide a sensitive measure of ecologically relevant changes in the environment (Philippi et al. 1998). One approach to achieve this is to determine plant community resemblance based on size structure. According to De Cáceres et al. (2013), in plant communities, the most natural structural variables for wood vegetation are plant height and trunk diameter. Abundance profiles of the plant community for a given area can be calculated with the values of the structural variables for each individual.

The main objective of this study was to analyze the early pedogenic trends and patterns of vegetation establishment in Technosols developed in dredged sediment deposits through the analysis of changes in morphological and physicochemical properties after different time periods since the deposition of dredged sediments, at different depths and for the two types of deposits found in the study site, i.e., gravel and sandy deposits. The specific aims of this study were (i) to investigate changes in soil morphological and physicochemical properties at early stages of pedogenesis, (ii) to estimate the variability of size structure of the new plant cover resulting from the time since dredged sediment disposal and deposit type, and (iii) to determine which soil parameters correlate best with the size structure distribution of the vegetation.

\section{Material and methods}

\subsection{Site description}

Both gravel and sandy deposits were established by hydraulic filling. The sediment deposits consisted of bottom sediments dredged from river sections in the neighborhood of the landfill site. The first stage in alluvial gold mining is to take the dredged riverbed material and separate the finer fractions where the gold is found from the larger mineral fraction. In a typical alluvial mining process, physical separation methods such as screen filters and gravity separation are used to separate the gold from the mineral fraction. After separation, the larger mineral fraction is pumped over the deposition sites. Gravel material is deposited by bucket dredges in strip-like patterns that are used to contain the sandy material pumped by 
suction dredges. At the time of the sampling, the ages of the sites varied between 1 and 12 years since deposition.

To mitigate the environmental impact of alluvial gold mining, frequent attempts have been made to establish vegetation on gravel and sandy deposits left by dredges. The Colombian company Mineros S.A. established farm forestry systems on gravel and sandy deposits created after alluvial gold exploitation with suction and bucket dredges. Farm forestry systems are defined as the growth of woody perennials on the same management unit as used for agricultural crops and animal husbandry, with both ecological and economical interactions between the woody and non-woody components of the system (Nair 1993). Vegetation establishment begins by flattening the topography with bulldozers in order to reduce the slope to below $30 \%$ for the subsequent establishment of a vegetation cover. Multipurpose trees are often planted on cropland, around homesteads, as shelterbelts, or for vegetation establishment on less fertile areas. Farmers commercialize the timber, use it as firewood, and often do tree beekeeping. The most common tree species found in the area are Cecropia peltata (Urticaceae), Acacia mangium (Fabaceae), Guazuma ulmifolia (Malvaceae), Miconia minutiflora (Melastomataceae), Sapium glandulosum (Euphorbiaceae), Tectona grandis (Lamiaceae), as well as shrubs such as Eupatorium vitalbae (Asteraceae), Vernonanthura patens (Asteraceae), and Rubus ulmifolius (Rosaceae). The most abundant herbaceous species in the area are Calathea lutea (Marantaceae) and Cyperus ferax (Cyperaceae). The aim of the company is to support agricultural land use by establishing crops in more fertile areas of the deposits while creating productivity on less fertile areas by planting trees. So far, under the Mineros S.A. initiative, more than 700 ha have been restored in this way and more than 40 farmers and their families have benefitted by the entitlement of 14-ha plots.

Based on a detailed survey of the Techosols derived from dredged sediments, four areas were chosen for this study based on the time since deposition of dredged sediments, as well as on the presence of both types of deposits. The study sites are located in northwest Colombia in the gold mining area of El Bagre, Antioquia (Fig. 1), in the humid tropical forest zone with an average temperature of $28{ }^{\circ} \mathrm{C}$ and an annual precipitation of 2000-4000 $\mathrm{mm}$. The region has a dry season from November to March and a rainy season from April to October. The topography is mostly flat with the characteristics of a low-lying forest that remains flooded most of the year, thereby preventing productive activities in agriculture, animal husbandry, or forestry. Such areas are the most affected by gold mining.

\subsection{Soil sampling and analysis}

Areas where dredged sediments had been deposited since 2002, 2006, 2010, and 2014 were selected for this study. Six sampling sites were chosen within each of the four areas giving a total of 24 sampling sites with 12 located in gravel deposits and 12 in sandy deposits. Soil samples were collected from September 2015 to February 2016 at depths of 0-20, 2040 , and $40-60 \mathrm{~cm}$. For soil sampling, an area of $10 \times 10 \mathrm{~m}$ was selected at each sampling site to describe the morphology of the soil profile, to perform field measurements of hydraulic conductivity, and to take samples for physicochemical soil analyses. For soil sampling, an auger with $10-\mathrm{cm}$ diameter was used for sandy deposits and a shovel for gravel deposits. Gravel is defined as any particle with 2-60 mm diameter.

Samples for bulk density were taken as undisturbed soil cores (10 cm diameter, $7 \mathrm{~cm}$ length) from each sampled surface layer. Bulk density was estimated with oven-dry cores $\left(105^{\circ} \mathrm{C}\right.$ for $48 \mathrm{~h}$ ). To estimate the water retention curve (field capacity, saturated water content, permanent wilting point $(\%$, $v / v)$ ), undisturbed cores (4 $\mathrm{cm}$ diameter, $6 \mathrm{~cm}$ length) were taken from each sampled surface layer. Saturated water content, field capacity (applied pressure 0.33 bar), and permanent wilting point (applied pressure 15 bar) were determined according to Richards and Weaver (1944). The structural stability index was computed following Yoder (1936). Soil texture was analyzed using the Bouyoucos hydrometer method. Hydraulic conductivity was measured in the field using a tension infiltrometer (Eijkelkamp, Netherlands) and a Guelph constant head permeameter (Eijkelkamp, Netherlands). Soil $\mathrm{pH}$ was determined by the potentiometric method 1:1 water, total organic carbon (TOC) by Walkey-Black, and total nitrogen (TN) by the Kjeldahl method. Available phosphorus (P) was assessed by a modified Bray-II method. Contents of potassium $(\mathrm{K})$, calcium $(\mathrm{Ca})$, magnesium $(\mathrm{Mg})$, iron $(\mathrm{Fe})$, manganese $(\mathrm{Mn})$, zinc $(\mathrm{Zn})$, copper $(\mathrm{Cu})$, and aluminum $(\mathrm{Al})$ were quantified by atomic absorption spectroscopy after extraction with $\mathrm{HCl}(37 \%, m / v)$. Altitude, longitude, and latitude were recorded using a portable GPS (Garmin eTrex 10, Germany).

\subsection{Soil morphology}

Soil morphology (Figs. 2 and 3) was studied following the guidelines developed by the US Soil Science Division Staff (2017). Soil pits were dug and the different horizons of the soil profiles identified. The morphology of each soil horizon was described according to the field-description handbook of Loaiza et al. (2015) and the FAO Guidelines for soil description (Jahn et al. 2006) for the following properties: presence of roots, root size, particle shape, particle size, color, structure, consistence, and stoniness. For the soil color description, Munsell color charts were used (Munsell 2013), and for the mineralogy analysis in the field, $\times 10-20$ lenses were used.

\subsection{Vegetation survey}

The measurement of the size structure of vegetation was conducted on the 24 sampling sites according to González et al. 


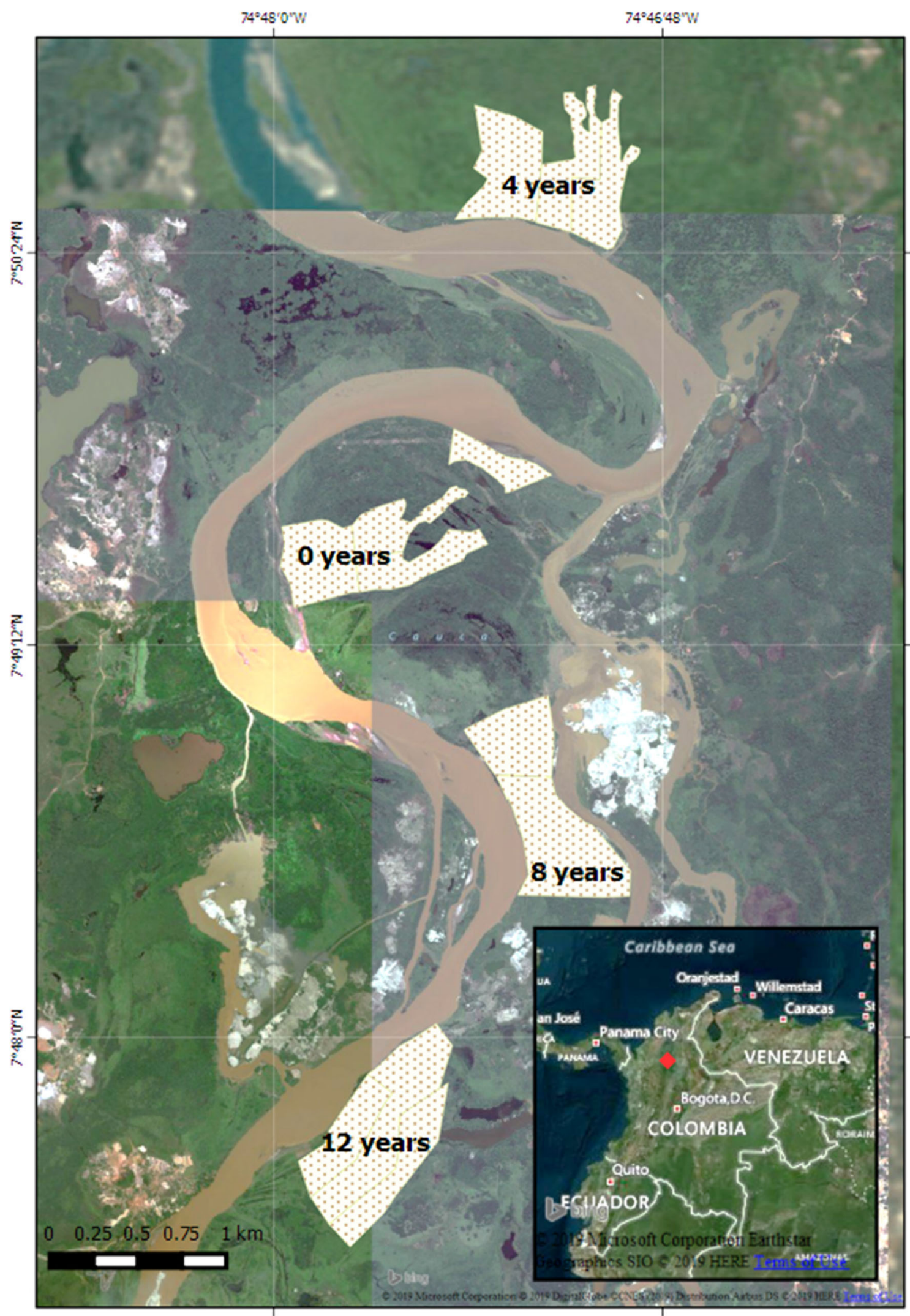

Fig. 1 Four areas in El Bagre, Antioquia, Colombia, covered by dredged sediment left by alluvial gold mining since 2002, 2006, 2010, and 2014 selected for characterization and vegetation measurements 
Fig. 2 Soil profile of gravel deposits in non-revegetated areas and 4,8 , and 12 years since dredged sediment deposition

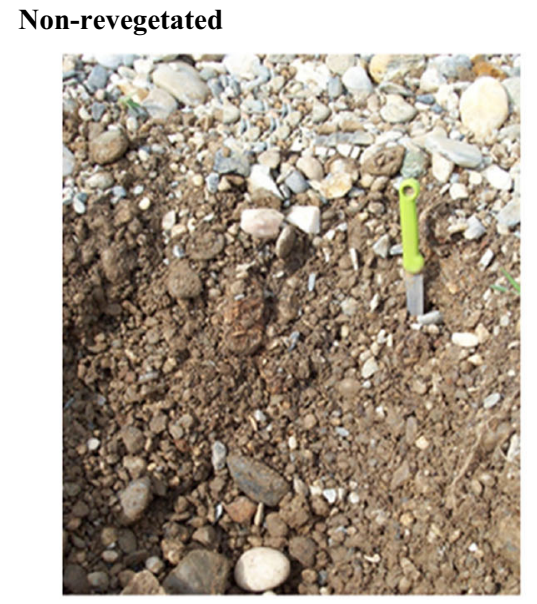

4 years

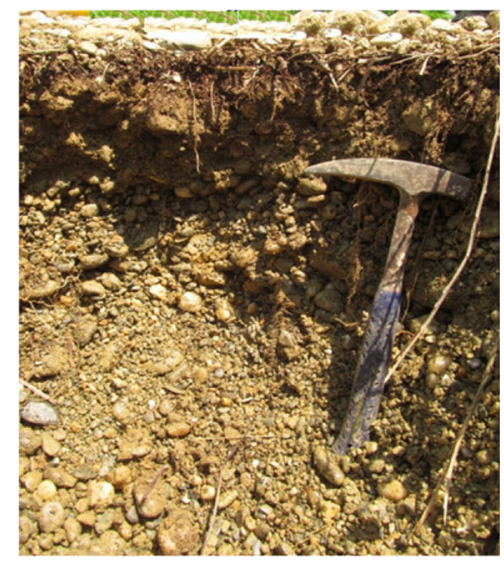

8 years

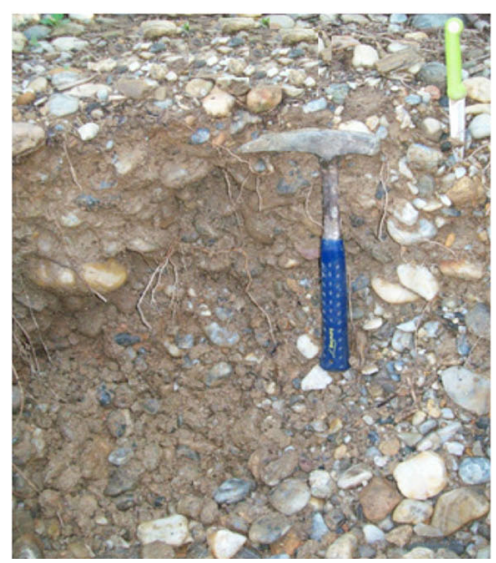

12 years

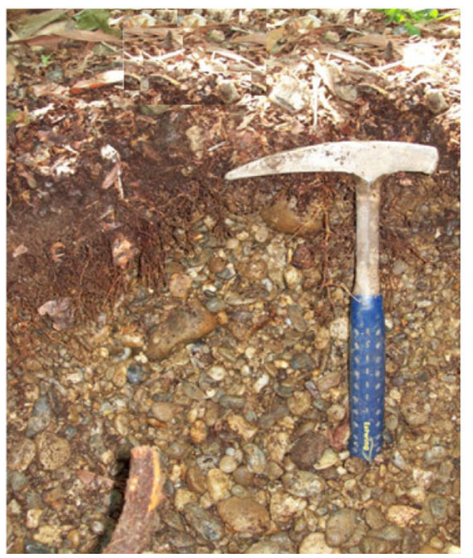

(2006). Trees and shrubs were georeferenced within the boundaries of the $10 \times 10 \mathrm{~m}$ plots, and diameter at breast height (DBH), as well as total height of each living plant was measured. Tree heights were measured with a Vertex IV hypsometer (Haglöf, Sweden).

\subsection{Data analysis}

In this study, data were strongly non-normal and resistant to transformation. Non-parametric tests rely on the assumption that the samples are independent and come from the same distribution and are usually less powerful than the corresponding parametric tests when the normality assumption holds. Nonparametric tests often require modifying the hypothesis, as the tests about the population center are about the median instead of the mean, which does not answer the same question as the corresponding parametric procedure (McArdle and Anderson 2001; Anderson 2001). In spite of this drawback, the use of non-parametric procedures was chosen as the best option for this study, as the sample size was in some cases not large enough to perform parametric analyses with strongly non- normal data. A three-way permutational multivariate analysis of variance (PERMANOVA) was conducted in which soil physicochemical properties were examined as a function of time period since dredged sediment deposition, sampling depth, and deposit type (gravel or sandy deposit). The $P$ values were calculated on 10,000 permutations of the data using the adonis function in the $\mathrm{R}$ vegan package (Oksanen et al. 2017). Kruskal-Wallis tests were used to independently compare each soil parameter associated with each deposit type. To visualize the results of the PERMANOVA, multivariate homogeneity of group variances was assessed by means of principal coordinate analysis. Each soil sampling point is depicted with its mean distance to the centroid of each grouping factor, which in this case is deposit type, time period since establishment of vegetation, and sampling depth. These figures were elaborated using the betadisp function in the $\mathrm{R}$ vegan package.

A linear discriminant analysis (LDA) was performed (Huberty and Morris 1989) to identify the soil properties that contributed most to differences between gravel and sandy deposits. For this purpose, the values of soil properties for both types of deposits were standardized and weights were 
Fig. 3 Soil profile of sandy deposits in non-revegetated areas and 4,8 , and 12 years since dredged sediment deposition

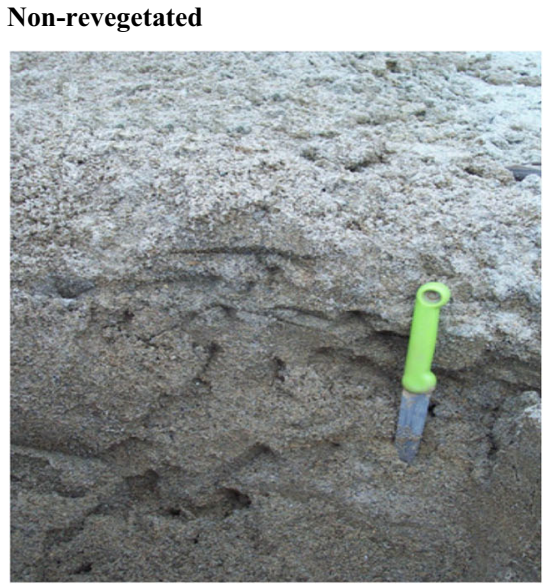

4 years

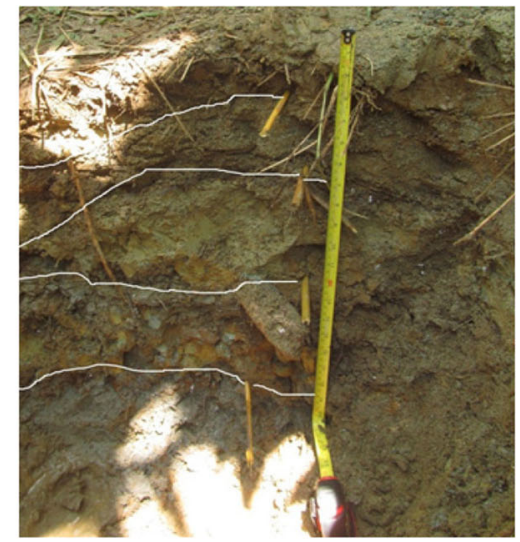

8 years

12 years

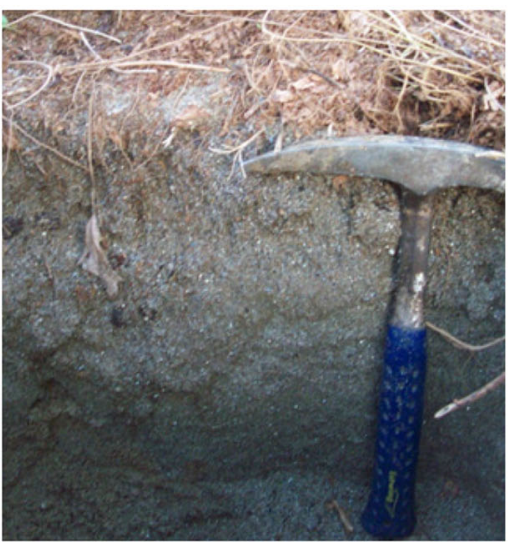

assigned to each soil property in terms of their discriminating power between gravel and sand. The soil properties with large weights were considered as those that contributed the most to differences between deposit types. This analysis was performed using the lda function of the R package MASS (Venables and Ripley 2002). A graphical representation of the two-dimensional partition done by LDA analysis was elaborated using the partimat function of the $\mathrm{R}$ package klaR (Weihs et al. 2005).

Abundance profiles of living plants were calculated for each plot to analyze the distribution of plant sizes. Based on the method developed by Clarke and Ainsworth (1993), an analysis was performed to identify the combination of soil properties that best explained the patterns observed in the size distribution of the plant community. For this, the bioenv function of the R package vegan was used to identify the most suitable subset of soil-physicochemical properties that best correlated with plant community similarity matrices constructed based on size distribution measurements (Oksanen et al. 2017). The most suitable subset of soil properties found after the bioenv analysis was further subjected to a permutation test using the adonis function in $\mathrm{R}$ to determine significance.

\section{Results}

\subsection{Soil morphology}

The morphological description of the Technosols for both gravel and sandy deposits (Tables 1 and 2) shows a superimposition of sub-horizontal layers, in some cases with wavy boundaries within layers. In the gravel deposits, fine roots were rare in the $\mathrm{C}$ horizons. However, frequent fine and medium roots could be observed in $\mathrm{O}$ horizons $(0-2 \mathrm{~cm})$. Formation of $\mathrm{O}$ horizons, dominated by organic material, was observed for gravel deposits $>4$ years after dredged sediment deposition, and for sandy deposits with $>8$ years after deposition. Different kinds of material were recorded in both gravel and sandy deposits $>4$ years after deposition, with changes in particle-size distribution and color. The upper layers of the gravel deposits exhibited a light brown color (10 YR4/3), and rounded and sub-rounded gravel, with a few fine roots in the younger gravel deposits, and abundant fine and medium roots in the gravel deposits with $>8$ years after deposition. Deeper in the profile, layers with various shades of yellow could be identified (5Y6/4, 5Y7/6). Coarse 
Table 1 Morphological description of profiles developed from gravel deposits for each period since dredged sediment deposition

\begin{tabular}{|c|c|c|c|}
\hline Year & Vegetation & Horizon & Description \\
\hline \multirow[t]{5}{*}{0} & \multirow[t]{5}{*}{ Pueraria phaseoloides } & \multirow[t]{5}{*}{$\mathrm{C}(0-50 \mathrm{~cm})$} & Color: 10YR4/3 (wet), 10YR5/4 (dry) \\
\hline & & & Structure: weak \\
\hline & & & Consistence: loose \\
\hline & & & Plasticity: non-plastic \\
\hline & & & $\begin{array}{l}\text { Other features: few fine roots. } 70 \% \text { gravel (diameter, } 0.2-1 \mathrm{~cm} \text { ), } \\
15 \% \text { gravel (diameter, } 1-2 \mathrm{~cm}), 15 \% \text { rounded and sub-rounded } \\
\text { gravel (diameter, } 2-10 \mathrm{~cm})\end{array}$ \\
\hline \multirow[t]{10}{*}{4} & \multirow[t]{10}{*}{ Moringa oleifera } & \multirow[t]{5}{*}{$\mathrm{O}(0-2 \mathrm{~cm})$} & Color: 10YR2/2 (wet) \\
\hline & & & Structure: weak \\
\hline & & & Consistence: loose \\
\hline & & & Plasticity: non-plastic, non-sticky \\
\hline & & & $\begin{array}{l}\text { Other features: moderately decomposed organic matter; } \\
\text { frequent fine and medium-sized roots; abundant } \\
\text { sub-rounded quartz grains, size of fine sand; } \\
\text { frequent light-colored mica, size of very fine sand; } \\
\text { abundant rock fragments, size of fine and medium sand; } \\
\text { frequent rock fragments (diameter, } 1-5 \mathrm{~mm} \text { ) }\end{array}$ \\
\hline & & \multirow[t]{5}{*}{$\mathrm{C}(2-45 \mathrm{~cm})$} & Color: 5Y6/4 (wet), 5Y7/6 (dry) \\
\hline & & & Structure: weak \\
\hline & & & Consistence: loose \\
\hline & & & Plasticity: non-plastic, non-sticky \\
\hline & & & $\begin{array}{l}\text { Other features: few fine roots. } 60 \% \text { gravel } \\
\quad(\text { diameter, } 0.5-1 \mathrm{~cm}), 30 \% \text { gravel } \\
\text { (diameter, } 1-4 \mathrm{~cm}), 10 \% \text { gravel (diameter, } 4-10 \mathrm{~cm})\end{array}$ \\
\hline \multirow[t]{5}{*}{8} & \multirow[t]{5}{*}{ Musa paradisiaca } & \multirow[t]{5}{*}{$\mathrm{C}(0-50 \mathrm{~cm})$} & Color: 10YR4/4 (wet) \\
\hline & & & Structure: weak \\
\hline & & & Consistence: loose \\
\hline & & & Plasticity: non-plastic, non-sticky \\
\hline & & & $\begin{array}{l}\text { Other features: abundant fine and medium roots; } \\
\text { frequent fine pores; } 80 \% \text { stoniness, } 50 / 50 \text { proportion } \\
\text { of gravel, rounded and sub-rounded gravel }\end{array}$ \\
\hline \multirow[t]{7}{*}{12} & \multirow[t]{7}{*}{ Psidium guajava; Acacia mangium } & \multirow[t]{5}{*}{$\mathrm{O}(0-4 \mathrm{~cm})$} & Color: 7.5 YR 5/3 (wet) \\
\hline & & & Structure: weak \\
\hline & & & Consistence: loose \\
\hline & & & Plasticity: non-plastic, non-sticky \\
\hline & & & $\begin{array}{l}\text { Other features: abundant fine and medium roots, } \\
\text { few thick roots; moderately to highly decomposed } \\
\text { organic matter }\end{array}$ \\
\hline & & \multirow[t]{2}{*}{$\mathrm{C}(>4 \mathrm{~cm})$} & Consistence: loose \\
\hline & & & $\begin{array}{l}\text { Other features: stoniness; loosen gravel; few fine roots; } \\
\text { deposit with } 80 \% \text { of rounded gravel }(\text { diameter, } 0.5-4 \mathrm{~cm} \text { ), } \\
20 \% \text { rounded stoniness (diameter, } 4-10 \mathrm{~cm} \text { ) }\end{array}$ \\
\hline
\end{tabular}

roots were noted in the gravel deposits 12 years after deposition. The upper layers of the sandy deposits were dark yellow and brown (2.5Y 5/4, 10 YR 4/3), with fine and medium roots in areas with $>4$ years after deposition. Abundant fragments of angular and sub-rounded quartz, as well as abundant coarse pores, occurred in the upper layers of the sandy deposits.

Redoximorphic features (Lindbo et al. 2010) were observed in the profile of sandy deposits $>4$ years after dredged sediment deposition, where the water table was found at a depth of $58 \mathrm{~cm}$. Accumulation of iron oxide in the root channels was found in sandy deposits with $>4$ years after deposition, indicating temporary changes in the redox potential. In addition, the presence of sapric material was found in the sandy deposit 8 years after deposition. Moderately decomposed organic matter occurred in gravel deposits with $>4$ years after deposition, and biological activity of mesofauna was found in the profile of sandy deposits 
Table 2 Morphological description of profiles developed from sandy deposits for each period since dredged sediment deposition

\begin{tabular}{|c|c|c|c|}
\hline Year & Vegetation & Horizon & Description \\
\hline \multirow[t]{4}{*}{0} & Pueraria phaseoloides & $\mathrm{C}(0-50 \mathrm{~cm})$ & Color: $2.5 \mathrm{Y} 5 / 4$ (wet), $2.5 \mathrm{Y} 5 / 2$ (dry) \\
\hline & & & Structure: weak \\
\hline & & & Consistence: loose \\
\hline & & & Plasticity: non-plastic, non-sticky \\
\hline
\end{tabular}

Other features: abundant angular quartz fragments, size of fine and very fine sand; frequent mafic angular and sub-rounded rock fragments; frequent sub-rounded quartz grains, size of very fine sand

Color: 10YR3/4 (wet)

Structure: weak

Plasticity: slightly plastic non-sticky

Other features: frequent fine roots; abundant fine and medium roots; abundant fine pores; abundant light-colored mica, size of very fine sand; roots with insects

C2 (7-15 cm) Color: 10 YR 4/3 (wet)

Structure: weak

Consistence: loose

Plasticity: non-plastic, non-sticky

Other features: coarse porosity; abundant quartz sub-rounded fragments, size of fine sand; abundant rock fragments, size of fine sand; frequent accumulation of iron oxide

Cg3 (15-29 cm) Color: $60 \% 2.5$ Y5/3 (wet), $40 \% 10$ YR3/6 (wet)

Structure: weak

Consistence: loose

Plasticity: slightly plastic and sticky

Other features: abundant fine roots; abundant fine pores; frequent accumulation of iron oxide in channels; frequent quartz grains, size of very fine sand

Cg4 (29-48 cm) Color: $80 \%$ 5Y5/1 (wet), 20\% 7.5YR 4/6 (wet)

Structure: weak

Consistence: loose

Plasticity: plastic and sticky

Other features: few fine roots, abundant fine pores; abundant accumulation of iron oxide in root channels; frequent mica fragments, size of very fine sand; evidence of redox processes; porosity associated with root channels with a vertical orientation; abundant fine root channels

C5 (> $48 \mathrm{~cm}$ ) Color: $90 \%$ GLEY $16 / 5$ GY (wet), $10 \%$ 7.5YR 5/8 (wet)

Structure: weak

Consistence: loose

Plasticity: non-plastic, non-sticky

Other features: abundant coarse pores; abundant quartz grains, rounded and sub-angular, size of fine and medium sand; abundant rock fragments, size of medium sand; frequent light-colored mica fragments, size of sand 
Table 2 (continued)

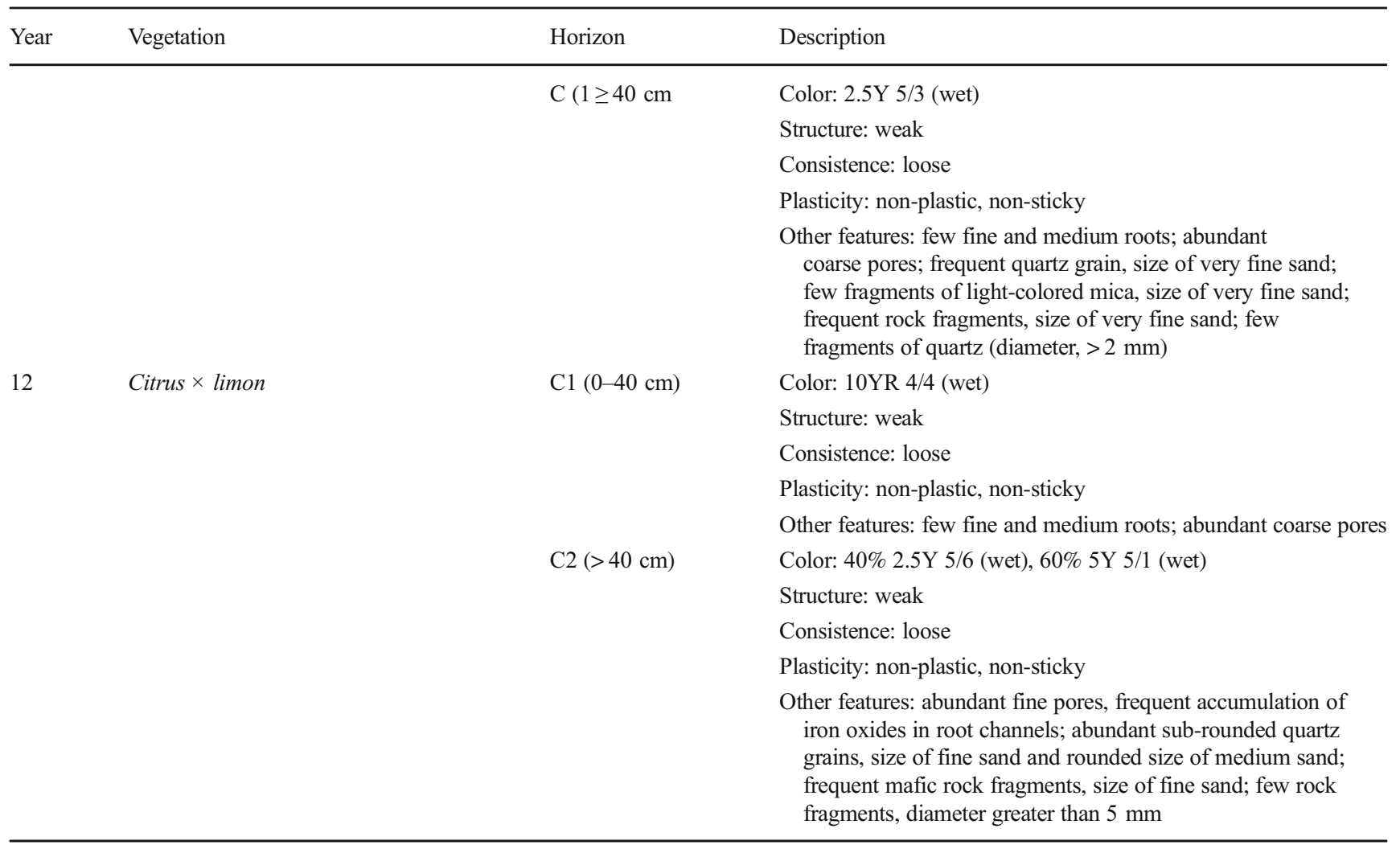

$>4$ years after deposition. As expected, in both sand and gravel deposits, the abundance and size of roots increased from younger to older areas.

\subsection{Physicochemical properties of Technosols}

Descriptive statistics of the physical properties of the deposits are shown in Table 3. The gravel fraction is usually considered as having no effect on the chemical and biological functioning of the soil and was therefore removed before the laboratory analysis. The gravel content represents $8.4 \pm 3.7 \%$ (SD) of the total weight of the samples taken in gravel deposits. The percentage of sand observed in the fraction with $<2 \mathrm{~mm}$ particle size of gravel deposits shows a moderate to high content of sand in non-revegetated areas and very high content in areas > 4 years after dredged sediment deposition. A moderate silt content was found in non-revegetated gravel deposits and low to moderate content in gravel deposits $>4$ years after deposition. The clay content was highest in non-revegetated gravel deposits and lowest in non-revegetated sandy deposits. A very high sand content was observed in non-revegetated sandy deposits but was lower in sandy deposits $>4$ years after deposition. Low silt contents were observed in nonrevegetated sandy deposits and low to moderate silt contents in sandy deposits 4 years after deposition, but these were lower in areas $>8$ years after deposition.
Stability index, bulk density, and hydraulic properties were measured for undisturbed samples without removing the gravel. A poor structural stability was observed in both gravel and sandy deposits. The highest stability indices were observed in non-revegetated sandy deposits. In general, moderate to low bulk density values were observed in both deposit types. Gravel and sandy deposits exhibited low water retention capacity and water contents at wilting point, characteristic of soils with a coarse texture. The water retention properties of the sand and gravel deposits showed similar values for both deposit types and all stages of vegetation establishment. The saturated hydraulic conductivity was higher in gravel deposits than in sandy deposits. A high variability of saturated hydraulic conductivity was observed for both gravel and sandy deposits for all time periods after dredged sediment deposition, ranging from very low to moderate values in both deposit types.

Soil acidity $(\mathrm{pH})$ and selected soil chemical properties are shown in Table 4 for both gravel and sandy deposits. Following up on the significant differences in chemical properties of the gravel deposits after different time periods since dredged sediment deposition, Kruskal-Wallis tests and KruskalWallis multiple comparisons were conducted for each individual chemical property of the gravel deposits. Results show significant changes in $\mathrm{pH}, \mathrm{P}, \mathrm{K}, \mathrm{Ca}, \mathrm{Cu}$, and $\mathrm{Na}$. Gravel deposits > 4 years after deposition have significantly lower $\mathrm{pH}$ and lower $\mathrm{P}$, $\mathrm{K}, \mathrm{Ca}, \mathrm{Cu}$, and $\mathrm{Na}$ values compared with gravel deposits that 
Table 3 Physical properties of soil for different deposit types and each period since dredged sediment deposition

\begin{tabular}{|c|c|c|c|c|c|c|c|c|c|}
\hline \multirow[t]{2}{*}{ Property } & \multirow{2}{*}{$\begin{array}{l}\text { Soil layer } \\
(\mathrm{cm})\end{array}$} & \multicolumn{2}{|c|}{ Non-revegetated area } & \multicolumn{2}{|l|}{4 years } & \multicolumn{2}{|l|}{8 years } & \multicolumn{2}{|l|}{12 years } \\
\hline & & Gravel & Sand & Gravel & Sand & Gravel & Sand & Gravel & Sand \\
\hline \multirow[t]{3}{*}{ Sand $(\%)$} & $0-20$ & $37 \pm 4.2$ & $93.3 \pm 2.9$ & $75.3 \pm 12.7$ & $44 \pm 3.8$ & $56.7 \pm 15.5$ & $77.3 \pm 15.3$ & $75.3 \pm 19.1$ & $70 \pm 21.1$ \\
\hline & $20-40$ & $50 \pm 7.1$ & $88 \pm 6.2$ & $70 \pm 12.5$ & $44.7 \pm 17.6$ & $60.3 \pm 8.1$ & $72.7 \pm 18.6$ & $62 \pm 40.5$ & $76.7 \pm 21.7$ \\
\hline & $40-60$ & $40 \pm 1$ & $89 \pm 1$ & $72.3 \pm 17$ & $77 \pm 11.3$ & $53.3 \pm 9.7$ & $71 \pm 17.1$ & $65.7 \pm 33.3$ & $73.3 \pm 34.9$ \\
\hline \multirow[t]{3}{*}{ Silt (\%) } & $0-20$ & $21.5 \pm 10.6$ & $4 \pm 0$ & $15 \pm 5$ & $39.7 \pm 26.3$ & $15.3 \pm 7.1$ & $16.7 \pm 11.9$ & $6 \pm 1.7$ & $6.7 \pm 4.0$ \\
\hline & $20-40$ & $24 \pm 7.1$ & $5.7 \pm 1.5$ & $13 \pm 10.6$ & $37.3 \pm 20.2$ & $10.7 \pm 2.1$ & $19.3 \pm 14.2$ & $6.3 \pm 5.5$ & $7.7 \pm 5.5$ \\
\hline & $40-60$ & $26.5 \pm 10.6$ & $5 \pm 1$ & $12.3 \pm 9.7$ & $11.5 \pm 10.6$ & $14 \pm 7.8$ & $14.7 \pm 12.6$ & $9 \pm 8.7$ & $12 \pm 14.7$ \\
\hline \multirow[t]{3}{*}{ Clay $(\%)$} & $0-20$ & $41.5 \pm 6.4$ & $2.7 \pm 2.9$ & $9.7 \pm 7.7$ & $16.3 \pm 9.5$ & $28 \pm 10$ & $6 \pm 5.2$ & $18.7 \pm 17.5$ & $23.3 \pm 17.9$ \\
\hline & $20-40$ & $16 \pm 14.14$ & $6.3 \pm 5.5$ & $17 \pm 5$ & $18 \pm 3.5$ & $29 \pm 7.6$ & $8 \pm 5$ & $31.7 \pm 36.8$ & $15.7 \pm 16.2$ \\
\hline & $40-60$ & $33.5 \pm 10.6$ & $6 \pm 0$ & $15.3 \pm 7.6$ & $11.5 \pm 0.7$ & $32.7 \pm 16.2$ & $14.3 \pm 5.5$ & $25.3 \pm 25.1$ & $14.7 \pm 20.2$ \\
\hline \multirow[t]{3}{*}{ Stability Index } & $0-20$ & 0.07 & $2.2 \pm 0.7$ & 0.08 & $0.19 \pm 0.2$ & $0.66 \pm 0.6$ & $2.23 \pm 1.5$ & 0.09 & $0.49 \pm 0.4$ \\
\hline & $20-40$ & 0.04 & $2.04 \pm 0.8$ & 0.09 & $0.42 \pm 0.3$ & $0.93 \pm 1.0$ & $0.98 \pm 1.2$ & 0.51 & $1.38 \pm 1.4$ \\
\hline & $40-60$ & 0.9 & $2.26 \pm 0.9$ & 0.12 & $0.4 \pm 0.5$ & $1.16 \pm 1.9$ & $0.42 \pm 0.6$ & 0.28 & $0.52 \pm 0.4$ \\
\hline \multirow[t]{3}{*}{ Bulk density $\left(\mathrm{g} \mathrm{cm}^{-3}\right)$} & $0-20$ & $1.39 \pm 0.4$ & $1.41 \pm 0.2$ & $1.50 \pm 0.2$ & $1.16 \pm 0.1$ & $1.4 \pm 0.1$ & $1.22 \pm 0.2$ & $1.34 \pm 0.1$ & $1.36 \pm 0.1$ \\
\hline & $20-40$ & $1.70 \pm 0.1$ & $1.23 \pm 0.1$ & $1.51 \pm 0.3$ & $1.15 \pm 0.2$ & $1.45 \pm 0.3$ & $1.13 \pm 0.2$ & $1.40 \pm 0.2$ & $1.32 \pm 0.2$ \\
\hline & $40-60$ & $1.65 \pm 0.3$ & $1.38 \pm 0.1$ & $1.34 \pm 0.5$ & $1 \pm 0.1$ & $1.16 \pm 0.3$ & $1.06 \pm 0.2$ & $1.40 \pm 0.3$ & $1.43 \pm 0.1$ \\
\hline \multirow[t]{3}{*}{ Field capacity $(\%)$} & $0-20$ & $10.1 \pm 1.6$ & $10.0 \pm 2.6$ & $10.1 \pm 3.1$ & $11.3 \pm 1.7$ & $11.9 \pm 0.4$ & $11.0 \pm 1.0$ & $8.3 \pm 1.6$ & $10.7 \pm 2.3$ \\
\hline & $20-40$ & $10.1 \pm 2.2$ & $10.0 \pm 3.3$ & $9.5 \pm 3.3$ & $9.6 \pm 2.9$ & $11.9 \pm 1.1$ & $10.6 \pm 1.9$ & $7.8 \pm 1.9$ & $10.8 \pm 2.4$ \\
\hline & $40-60$ & $10.8 \pm 0.3$ & $9.7 \pm 2.7$ & $10.8 \pm 1.3$ & $8.8 \pm 4$ & $8.5 \pm 3.4$ & $10.9 \pm 1.6$ & $8.6 \pm 2.6$ & $11.4 \pm 0.7$ \\
\hline \multirow[t]{3}{*}{ Saturated water content $(\%)$} & $0-20$ & $14.5 \pm 3.7$ & $15.0 \pm 3.9$ & $14.9 \pm 4.4$ & $17.3 \pm 2.9$ & $16.8 \pm 1.3$ & $16.4 \pm 1.4$ & $12.4 \pm 2.4$ & $15.7 \pm 2.8$ \\
\hline & $20-40$ & $14.5 \pm 4.7$ & $13.9 \pm 3.7$ & $14.0 \pm 5.3$ & $13.8 \pm 3.4$ & $17.1 \pm 0.9$ & $14.9 \pm 2.8$ & $11.4 \pm 3.2$ & $15.9 \pm 3.5$ \\
\hline & $40-60$ & $15.1 \pm 1.2$ & $14.6 \pm 4.2$ & $16.1 \pm 1.8$ & $13.1 \pm 6$ & $12.7 \pm 5.1$ & $16.3 \pm 2.4$ & $12.3 \pm 3.7$ & $16.8 \pm 1.3$ \\
\hline \multirow{3}{*}{$\begin{array}{l}\text { Permanent wilting point } \\
\quad(\%)\end{array}$} & $0-20$ & $5.1 \pm 1.7$ & $5.1 \pm 2.1$ & $5.6 \pm 1.7$ & $6.2 \pm 0.9$ & $6.6 \pm 0.2$ & $4.9 \pm 1.5$ & $4.5 \pm 0.8$ & $5.9 \pm 1.3$ \\
\hline & $20-40$ & $5.1 \pm 2.0$ & $5.14 \pm 2.5$ & $5.2 \pm 1.8$ & $5.3 \pm 1.6$ & $6.5 \pm 0.6$ & $5.3 \pm 1.6$ & $4.3 \pm 1.1$ & $5.9 \pm 1.3$ \\
\hline & $40-60$ & $6.1 \pm 0.4$ & $5.31 \pm 1.5$ & $5.9 \pm 0.6$ & $4.8 \pm 2.2$ & $4.3 \pm 2.3$ & $5.4 \pm 1.5$ & $4.8 \pm 1.3$ & $6.2 \pm 0.5$ \\
\hline$K_{\text {sat }}\left(\mathrm{cm} \mathrm{h}^{-1}\right)$ & Surface & $1.9 \pm 3.2$ & $0.3 \pm 0.2$ & $0.4 \pm 0.5$ & $3 \pm 0.01$ & $5.0 \pm 8.3$ & $0.1 \pm 0.1$ & $0.3 \pm 0.1$ & $0.1 \pm 0.1$ \\
\hline
\end{tabular}

Results are reported as mean \pm standard deviation. If standard deviation is not reported, measurements rely on one only sample for each factor $K_{\text {sat }}$, saturated hydraulic conductivity near the surface

were still without vegetation cover. The $\mathrm{pH}$ values for gravel deposits range from nearly neutral in non-revegetated areas to strongly acidic in areas 12 years after deposition. The TN content of gravel deposits is $20 \%$ higher in areas 12 years after deposition compared with non-revegetated areas. The content of TOC is $23 \%$ higher for gravel deposits 12 years after deposition compared with newly established areas. The content of exchangeable cations is considerably lower in gravel deposits revegetated for $>$ 4 years compared with non-revegetated areas. Fe and $\mathrm{Zn}$ content is higher in gravel deposits with $>4$ years after deposition. The $\mathrm{Cu}$ content is lower in gravel deposits $>4$ years after deposition.

\subsection{Variation of physicochemical properties of Technosols between deposit types, time period since establishment, and sampling depth}

The results of a PERMANOVA (Table 5) show that soil chemical properties vary significantly between gravel and sandy deposits $(p=0.005)$. In addition, there is a significant interaction between two factors, i.e., deposit type and year of establishment $(p=0.02)$. Following up on the interaction, a permutational analysis of variance of soil-chemical properties for each deposit type (gravel and sandy deposits) was performed independently for the different time periods since dredged sediment deposition. The results show that gravel deposits exhibit highly significant changes $(p<0.001)$ in chemical properties among different time periods since establishment of vegetation. However, there is no significant difference in the chemical properties of sandy deposits among the different time periods of vegetation establishment. No significant differences can be observed in gravel or sandy deposits at different sampling depths. In addition, the results of the PERMANOVA of soil physical properties (results not presented) reveal no significant changes among deposit type, time period since establishment of vegetation, or sampling depth.

A graphical visualization of the results of the PERMANOVA by means of principal coordinate analysis (Fig. 4) shows that the first and second axes explain 84.4 and $12.7 \%$, respectively, of the total variability. Figure $4 \mathrm{a}$ 
Table 4 Soil-chemical properties for different deposit types and each period since dredged sediment deposition

\begin{tabular}{|c|c|c|c|c|c|c|c|c|c|}
\hline \multirow[t]{2}{*}{ Property } & \multirow[t]{2}{*}{ Soil layer $(\mathrm{cm})$} & \multicolumn{2}{|c|}{ Non-revegetated area } & \multicolumn{2}{|l|}{4 years } & \multicolumn{2}{|l|}{8 years } & \multicolumn{2}{|l|}{12 years } \\
\hline & & Gravel & Sand & Gravel & Sand & Gravel & Sand & Gravel & Sand \\
\hline \multirow[t]{3}{*}{$\mathrm{pH}$} & $0-20$ & $6.95 \pm 0.2$ & $5.73 \pm 0.2$ & $5.13 \pm 0.5$ & $4.90 \pm 0.4$ & $4.97 \pm 0.2$ & $4.90 \pm 0.5$ & $4.87 \pm 0.3$ & $5.43 \pm 0.4$ \\
\hline & $20-40$ & $7.10 \pm 0.3$ & $5.70 \pm 0.2$ & $5.13 \pm 0.6$ & $5.07 \pm 0.5$ & $5.27 \pm 0.4$ & $4.53 \pm 0.2$ & $5.07 \pm 0.6$ & $5.60 \pm 0.0$ \\
\hline & $40-60$ & $7.05 \pm 0.1$ & $5.67 \pm 0.2$ & $5.43 \pm 0.5$ & $5.01 \pm 0.1$ & $5.17 \pm 0.4$ & $4.63 \pm 0.5$ & $5.50 \pm 0.4$ & $5.57 \pm 0.2$ \\
\hline \multirow[t]{3}{*}{$\mathrm{TN}(\%)$} & $0-20$ & $0.32 \pm 0.1$ & $0.28 \pm 0.02$ & $0.36 \pm 0.1$ & $0.32 \pm 0.04$ & $0.34 \pm 0.04$ & $0.30 \pm 0.0$ & $0.40 \pm 0.1$ & $0.33 \pm 0.0$ \\
\hline & $20-40$ & $0.29 \pm 0.02$ & $0.26 \pm 0.01$ & $0.31 \pm 0.03$ & $0.34 \pm 0.04$ & $0.35 \pm 0.1$ & $0.32 \pm 0.0$ & $0.43 \pm 0.2$ & $0.34 \pm 0.1$ \\
\hline & $40-60$ & $0.27 \pm 0.01$ & $0.28 \pm 0.02$ & $0.35 \pm 0.1$ & $0.33 \pm 0.04$ & $0.40 \pm 0.1$ & $0.33 \pm 0.0$ & $0.41 \pm 0.1$ & $0.29 \pm 0.0$ \\
\hline \multirow[t]{3}{*}{ TOC (\%) } & $0-20$ & $7.63 \pm 1.6$ & $6.28 \pm 0.5$ & $8.70 \pm 1.3$ & $7.42 \pm 1.0$ & $8.13 \pm 1.0$ & $6.84 \pm 0.7$ & $9.99 \pm 4.5$ & $7.71 \pm 0.3$ \\
\hline & $20-40$ & $6.74 \pm 0.8$ & $5.91 \pm 0.1$ & $7.25 \pm 0.7$ & $8.22 \pm 1.1$ & $8.44 \pm 1.3$ & $7.48 \pm 1.2$ & $10.19 \pm 4.8$ & $8.09 \pm 1.7$ \\
\hline & $40-60$ & $6.21 \pm 0.1$ & $6.42 \pm 0.4$ & $8.44 \pm 2.1$ & $7.74 \pm 1.1$ & $9.78 \pm 1.0$ & $7.89 \pm 0.7$ & $10.03 \pm 4.4$ & $6.73 \pm 0.4$ \\
\hline \multirow[t]{3}{*}{$K\left(\mathrm{cmol} \mathrm{kg}^{-1}\right)$} & $0-20$ & $0.62 \pm 0.2$ & $0.33 \pm 0.04$ & $0.40 \pm 0.1$ & $0.35 \pm 0.03$ & $0.49 \pm 0.1$ & $0.45 \pm 0.2$ & $0.42 \pm 0.1$ & $0.33 \pm 0.1$ \\
\hline & $20-40$ & $0.61 \pm 0.1$ & $0.34 \pm 0.1$ & $0.41 \pm 0.1$ & $0.44 \pm 0.1$ & $0.41 \pm 0.1$ & $0.38 \pm 0.1$ & $0.40 \pm 0.1$ & $0.31 \pm 0.1$ \\
\hline & $40-60$ & $0.49 \pm 0.01$ & $0.35 \pm 0.1$ & $0.39 \pm 0.1$ & $0.30 \pm 0.04$ & $0.44 \pm 0.04$ & $0.35 \pm 0.0$ & $0.37 \pm 0.1$ & $0.33 \pm 0.04$ \\
\hline \multirow[t]{3}{*}{$\mathrm{Ca}\left(\mathrm{cmol} \mathrm{kg}^{-1}\right)$} & $0-20$ & $14.12 \pm 0.8$ & $2.92 \pm 0.4$ & $6.75 \pm 3.0$ & $5.86 \pm 2.7$ & $6.44 \pm 1.3$ & $3.38 \pm 1.6$ & $5.90 \pm 2.0$ & $3.56 \pm 1.9$ \\
\hline & $20-40$ & $8.93 \pm 5.7$ & $2.83 \pm 0.1$ & $5.95 \pm 2.2$ & $6.82 \pm 0.3$ & $5.55 \pm 1.2$ & $3.79 \pm 1.7$ & $5.62 \pm 2$ & $3.08 \pm 1.5$ \\
\hline & $40-60$ & $10.98 \pm 3.0$ & $2.76 \pm 0.1$ & $6.11 \pm 1.8$ & $3.82 \pm 1.6$ & $6.51 \pm 0.9$ & $3.99 \pm 1.6$ & $5.89 \pm 2.5$ & $2.98 \pm 1.3$ \\
\hline \multirow[t]{3}{*}{$\operatorname{Mg}\left(\mathrm{cmol} \mathrm{kg}^{-1}\right)$} & $0-20$ & $5.60 \pm 0.1$ & $0.91 \pm 0.1$ & $2.97 \pm 1.9$ & $2.45 \pm 0.9$ & $2.96 \pm 1.1$ & $1.28 \pm 0.4$ & $2.99 \pm 2.6$ & $3.27 \pm 2.9$ \\
\hline & $20-40$ & $3.95 \pm 2.2$ & $0.88 \pm 0.01$ & $2.89 \pm 1.5$ & $3.21 \pm 0.2$ & $2.54 \pm 0.8$ & $1.55 \pm 0.5$ & $3.19 \pm 2.8$ & $2.71 \pm 2.8$ \\
\hline & $40-60$ & $4.97 \pm 0.4$ & $0.89 \pm 0.1$ & $2.69 \pm 1.0$ & $1.62 \pm 0.8$ & $2.94 \pm 0.9$ & $1.63 \pm 0.5$ & $2.70 \pm 1.8$ & $2.64 \pm 2.7$ \\
\hline \multirow[t]{3}{*}{$\mathrm{Na}\left(\mathrm{cmol} \mathrm{kg}^{-1}\right)$} & $0-20$ & $0.30 \pm 0.2$ & $0.14 \pm 0.01$ & $0.17 \pm 0.03$ & $0.20 \pm 0.1$ & $0.19 \pm 0.03$ & $0.12 \pm 0.02$ & $0.15 \pm 0.1$ & $0.14 \pm 0.1$ \\
\hline & $20-40$ & $0.52 \pm 0.3$ & $0.13 \pm 0.01$ & $0.19 \pm 0.1$ & $0.24 \pm 0.1$ & $0.20 \pm 0.1$ & $0.13 \pm 0.03$ & $0.18 \pm 0.1$ & $0.12 \pm 0.1$ \\
\hline & $40-60$ & $0.31 \pm 0.1$ & $0.31 \pm 0.3$ & $0.2 \pm 0.1$ & $0.14 \pm 0.02$ & $0.21 \pm 0.03$ & $0.13 \pm 0.02$ & $0.15 \pm 0.1$ & $0.12 \pm 0.1$ \\
\hline \multirow[t]{3}{*}{$\mathrm{Al}^{\mathrm{a}}\left(\mathrm{cmol} \mathrm{kg}^{-1}\right)$} & $0-20$ & N/A & N/A & 1.1 & $1 \pm 1$ & 1 & $1 \pm 0.1$ & $1 \pm 0.3$ & 1.2 \\
\hline & $20-40$ & N/A & N/A & 1 & $1 \pm 0.3$ & $1 \pm 0.1$ & $1 \pm 1$ & $1 \pm 0.1$ & N/A \\
\hline & $40-60$ & N/A & N/A & 0.7 & $0.6 \pm 0.1$ & 2 & $2 \pm 0.4$ & $1 \pm 0.1$ & N/A \\
\hline \multirow[t]{3}{*}{$\mathrm{P}\left(\mathrm{mg} \mathrm{kg}^{-1}\right)$} & $0-20$ & $198 . \pm 10$ & $11 \pm 3$ & $10 \pm 10$ & $5 \pm 3$ & $6 \pm 1$ & $13 \pm 9$ & $7 \pm 8$ & $5 \pm 4$ \\
\hline & $20-40$ & $87 \pm 111$ & $9 \pm 2$ & $14 \pm 18$ & $4 \pm 2$ & $4 \pm 4$ & $8 \pm 3$ & $10 \pm 3$ & $8 \pm 8$ \\
\hline & $40-60$ & $149 \pm 182$ & $13 \pm 3$ & $9 \pm 6$ & $10 \pm 1$ & $4 \pm 5$ & $8 \pm 2$ & $7 \pm 5$ & $6 \pm 6$ \\
\hline \multirow[t]{3}{*}{$\mathrm{Fe}\left(\mathrm{mg} \mathrm{kg}^{-1}\right)$} & $0-20$ & $67 \pm 40$ & $63 \pm 2$ & $165 \pm 85$ & $190 \pm 70$ & $112 \pm 10$ & $90.33 \pm 75$ & $121 \pm 72$ & $78 \pm 21$ \\
\hline & $20-40$ & $100 \pm 6$ & $61 \pm 6$ & $110 \pm 72$ & $232 \pm 104$ & $104 \pm 39$ & $202 \pm 152$ & $171 \pm 124$ & $71 \pm 42$ \\
\hline & $40-60$ & $98 \pm 23$ & $56 \pm 8$ & $112 \pm 73$ & $125 \pm 40$ & $142 \pm 64$ & $172 \pm 160$ & $178 \pm 140$ & $67 \pm 49$ \\
\hline \multirow[t]{3}{*}{$\operatorname{Mn}\left(\mathrm{mg} \mathrm{kg}^{-1}\right)$} & $0-20$ & $29 \pm 0.8$ & $61 \pm 7$ & $74 \pm 51$ & $83 \pm 38$ & $75 \pm 16$ & $74.86 \pm 71$ & $44 \pm 9$ & $84 \pm 29$ \\
\hline & $20-40$ & $25 \pm 18$ & $62 \pm 9$ & $90 \pm 71$ & $89 \pm 35$ & $91 \pm 43$ & $53.57 \pm 15$ & $85 \pm 4.84$ & $52 \pm 18$ \\
\hline & $40-60$ & $31 \pm 7$ & $64 \pm 11$ & $88 \pm 56$ & $57 \pm 52$ & $63 \pm 28$ & $65.63 \pm 30$ & $65 \pm 34.42$ & $53 \pm 19$ \\
\hline \multirow[t]{3}{*}{$\mathrm{Zn}\left(\mathrm{mg} \mathrm{kg}^{-1}\right)$} & $0-20$ & $7 \pm 4$ & $1 \pm 0.4$ & $15 \pm 9$ & $4 \pm 2$ & $16 \pm 19$ & $0.99 \pm 1$ & $13 \pm 19.42$ & $1 \pm 0.3$ \\
\hline & $20-40$ & $8 . \pm 7$ & $1 \pm 0.4$ & $13 \pm 14$ & $3 \pm 1$ & $23 \pm 22$ & $2 \pm 2$ & $21 \pm 32.14$ & $1 \pm 0.1$ \\
\hline & $40-60$ & $9 \pm 4$ & $1 \pm 0.6$ & $17 \pm 15$ & $2 \pm 1$ & $26 \pm 22$ & $2 \pm 1$ & $25 \pm 40.79$ & $2 \pm 1$ \\
\hline \multirow[t]{3}{*}{$\mathrm{Cu}\left(\mathrm{mg} \mathrm{kg}^{-1}\right)$} & $0-20$ & $7 \pm 3$ & $1 \pm 0.1$ & $4 \pm 2$ & $9 \pm 5$ & $4 \pm 1$ & $2 \pm 1$ & $5 \pm 2.48$ & $5 \pm 5$ \\
\hline & $20-40$ & $10 \pm 5$ & $1 . \pm 0.2$ & $4 \pm 2$ & $12 \pm 4$ & $4 \pm 1$ & $4 \pm 3$ & $4 \pm 2.85$ & $3 \pm 2$ \\
\hline & $40-60$ & $9 \pm 0.1$ & $1 \pm 0.1$ & $4 \pm 2$ & $6 \pm 3$ & $6 . \pm 3$ & $5 \pm 4$ & $6 \pm 5.18$ & $2 \pm 1$ \\
\hline
\end{tabular}

The gravel content represents $8.4 \pm 3.7 \%(\mathrm{SD})$ of the total weight of the samples taken in gravel deposits. Results are reported as mean \pm standard deviation

${ }^{a}$ Aluminum was only analyzed for samples with $\mathrm{pH}$ equal or lower than 5.1; therefore, for some of the results, standard deviation is not reported

shows a slight separation between different time periods since establishment but a greater overlay between the different sampling points. When deposit type is used as grouping factor,
Fig. $4 \mathrm{~b}$ shows a clearer separation between the levels of the grouping factor, i.e., gravel and sandy deposits. Figure $4 \mathrm{c}$ shows a complete overlay of the three levels of the grouping 
Table 5 Results of three-way permutational analysis of variance for soil chemical properties

\begin{tabular}{|c|c|c|c|c|c|c|}
\hline Factor & DF & Sum of squares & $\begin{array}{l}\text { Mean } \\
\text { squares }\end{array}$ & $F$ & $R^{2}$ & $\operatorname{Pr}(>F)$ \\
\hline Deposit type & 1 & 0.31 & 0.31 & 5.01 & 0.07 & $0.005 *$ \\
\hline Time period since establishment of vegetation & 1 & 0.13 & 0.13 & 2.06 & 0.03 & 0.09 \\
\hline Sampling depth & 2 & 0.01 & 0.007 & 0.11 & 0.003 & 0.99 \\
\hline Interaction: deposit type - time period since establishment of vegetation & 1 & 0.23 & 0.23 & 3.77 & 0.05 & $0.02 *$ \\
\hline Deposit type: gravel—factor: time period since establishment of vegetation & 1 & 0.42 & 0.42 & 6.11 & 0.16 & $0.0003 *$ \\
\hline Deposit type: sand — factor: time period since establishment of vegetation & 1 & 0.0001 & 0.0001 & 0.002 & 0.005 & 0.99 \\
\hline Interaction: deposit type-sampling depth & 2 & 0.06 & 0.03 & 0.49 & 0.01 & 0.83 \\
\hline Interaction: time period since establishment of vegetation — sampling depth & 2 & 0.03 & 0.01 & 0.22 & 0.006 & 0.98 \\
\hline $\begin{array}{l}\text { Interaction: deposit type - time period since establishment of vegetation—sampling } \\
\text { depth }\end{array}$ & 2 & 0.05 & 0.02 & 0.40 & 0.011 & 0.90 \\
\hline Residuals & 56 & 3.41 & 0.06 & & 0.81 & \\
\hline Total & 67 & 4.22 & & & 1 & \\
\hline
\end{tabular}

$D F$, degrees of freedom

*Significant differences

factor, i.e., the three sampling depths. Figure 4 shows that the effect of deposit type is greater and more significant in explaining the variability of soil properties compared with time period since establishment of vegetation or sampling depth.

The results of the PERMANOVA did not show significant differences in the chemical properties of sandy deposits after different time periods since dredged sediment deposition. Descriptive statistics (Table 3) of individual properties show that $\mathrm{pH}$ values are strongly acidic in most cases for the sandy deposits in the four studied areas and do not exhibit high variability in the three studied sampling depths. No accumulation of TOC and $\mathrm{TN}$ can yet be observed $>12$ years after deposition. Exchangeable cations and $\mathrm{Fe}$ content are higher in sandy deposits $>4$ years after deposition. Similar $\mathrm{Zn}$ values are found for the sandy deposits of the nonrevegetated and revegetated areas. The $\mathrm{Cu}$ contents are similar in sandy deposits at all times after sediment deposition.

Linear discriminant analysis (LDA) shows that $\mathrm{Ca}$ and $\mathrm{P}$ content contributes the most to differentiating gravel and sandy deposits, and that $\mathrm{Zn}, \mathrm{Al}, \mathrm{Cu}$, and $\mathrm{Fe}$ are also of considerable importance (Fig. 5). Differences in Ca content explain $26.7 \%$ of the variability between gravel and sandy deposits, being the parameter that has the highest differentiation capacity between both deposit types. Phosphorus and $\mathrm{Zn}$ content each explain $12 \%$ of the variability between gravel and sandy deposits, followed by contents of $\mathrm{Al}$ (11\%), $\mathrm{Cu}(10.7 \%)$, and Fe (10.4\%). Two-dimensional partitions (Fig. 5) of the soil properties with highest discriminant capacity ( $\mathrm{Ca}, \mathrm{P}, \mathrm{Zn}, \mathrm{Al}$ ) show that the lowest error rates for classification between gravel and sandy deposits based on soil properties are obtained when $\mathrm{Ca}$ and $\mathrm{Zn}$ are used for partition, followed by $\mathrm{Ca}$ and $\mathrm{Al}$. This indicates that the most relevant chemical properties that differentiate gravel and sandy deposits are the $\mathrm{Ca}, \mathrm{Zn}$, and $\mathrm{Al}$ content.

\subsection{Development of the vegetation cover}

Height distribution of trees and shrubs was determined in different years of vegetation establishment for both deposit types (Fig. 6). Profiles show that smaller trees $<5 \mathrm{~m}$ in height predominated on the plots $>4$ years after dredged sediment deposition. A few taller trees ( $>10 \mathrm{~m}$ height) were found $<$ 4 years after deposition and were more abundant in areas $>$ 8 years after deposition. The height profiles also reveal that the number of living trees in each height range was higher for gravel than for sandy deposits.

For shrubs, the height distribution reveals similar numbers of individuals among the different height ranges for both deposit types $>4$ years after dredged sediment deposition. However, gravel deposits $>8$ years had higher numbers in all height ranges compared with younger deposits. Analysis of similarity based on the Bray-Curtis index (Clarke 1993) shows that the time period since deposition had a greater effect $(R=0.27, p=0.001)$ on changes in size distribution (height) of trees than the deposit type $(R=$ $0.04, p=0.001)$. However, for height distribution of shrubs, it was observed that time period since establishment had a similar effect $(R=0.19, p=0.001)$ to that of deposit type $(R=0.19, p=0.001)$.

Analysis of the density of trees and shrubs in terms of living individuals per square meter shows significant changes in the density of trees, with significantly higher values $(p=0.01)$ for areas $>4$ years after dredged 
a)

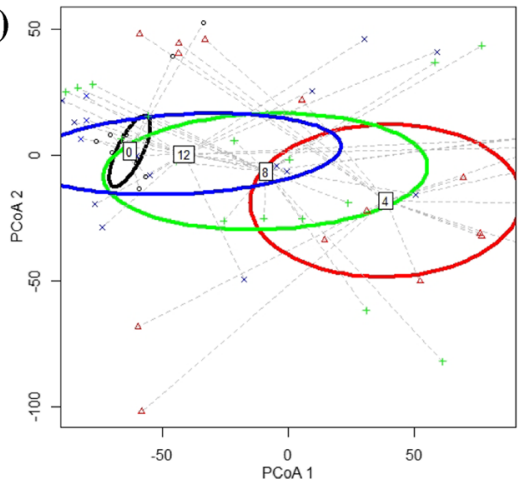

b)

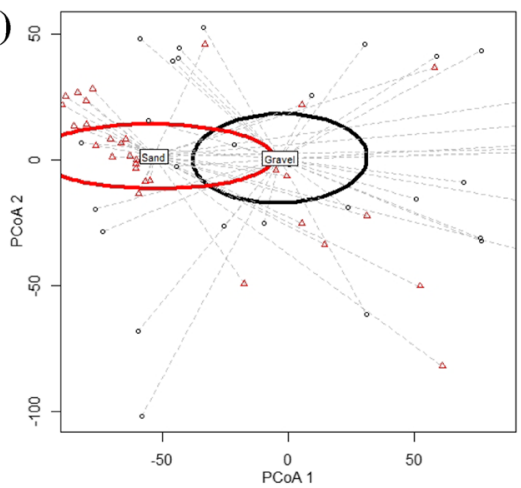

c)

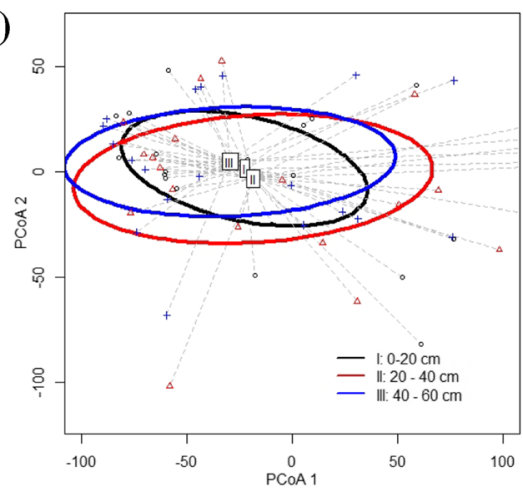

Fig. 4 Principal coordinate analysis of soil properties with grouping factors: a years since dredged sediment deposition, $\mathbf{b}$ deposit type, and c sampling depth. Dashed lines represent mean distance to centroid of each set of soil properties representing a sampling point to each level of the grouping factor. First and second axes explain 84.4 and $12.7 \%$ of the total variability, respectively

sediment deposition. No significant differences are observed for shrubs among the different time periods since deposition or between gravel and sandy deposits. Linking the size structure of the plant community to the variations of the chemical properties of the Technosol shows that $\mathrm{pH}$ $(p=0.034), \mathrm{P}(p=0.023)$, and $\mathrm{Mg}(p=0.039)$ had the strongest influence (Spearman correlation $=0.4365$ ) on the height distribution of the plant community compared with the other chemical properties, as their variability follows similar patterns to those of height distribution of plant community.

\section{Discussion}

The Technosols developed from dredged sediment deposits are originally highly diverse and heterogeneous because of the fact that the materials are deposited during cumulative events across time and the disturbances after deposition such as mixing and flattening. This heterogeneity can increase with time, as the nature of the parent materials, their particle size, and soil porosity affect pedogenesis, possibly at distinct rates at smaller scales especially during early stages of formation (Huot et al. 2015). Furthermore, local heterogeneities may change the hydrodynamic of the soil and constrain the development of organisms, which can result in constraints for plant colonization and uneven vegetation coverage (Huot et al. 2015).

Despite their young age, Technosols developed from dredged sediment deposits produced by alluvial gold mining are subject to pedogenic processes under the influence of climatic conditions and the development of a vegetation cover. The Technosols undergo processes that are similar to those occurring in natural materials such as mineral transformations, changes in redox conditions, organic matter accumulation at the surface, and a relatively rapid differentiation of horizons. The studied Technosols show an unusually high rate of development not often observed in natural soils, as drastic changes can be observed at very early stages of formation. Just like in natural soils, the colonization by organisms is the main driver of development of soils formed from technogenic materials (Jangorzo et al. 2015). Based on the analysis of size distribution of tree and shrub communities, gravel deposits seem to offer more favorable conditions for the growth of woody plant species than sandy deposits. Therefore, gravel deposits are likely to have a higher rate of pedogenic processes compared with sandy deposits. The evolution of gravel deposits could be dominated by the disequilibrium between the dredged sediments that form the deposits and the environment, which could generate intense changes during initial stages of pedogenesis. In addition, the colonization by organisms in gravel deposits could start a new phase of development characterized by processes driven by biological activity (Huot et al. 2015). Sandy deposits are likely to have a polycyclic evolution at slower rates, dominated by an acidification process unless soil amendments (i.e., lime, ash) are applied, and will prevent vegetation development and slow down the biological pedogenic processes even further.

In the studied Technosols, there is clear evidence of the rapid development of new horizons, visually distinguished according to color and root density in both types of deposits. The formation of O horizons in soils $>4$ years after dredged sediment deposition evidences the development of an increasingly abundant plant cover that consequently increases the amounts of TOC in topsoil with increasing age (Uzarowicz et al. 2017). The presence of sapric material, as well as the biological activity $>4$ years after deposition, suggests that porosity and aggregation processes 


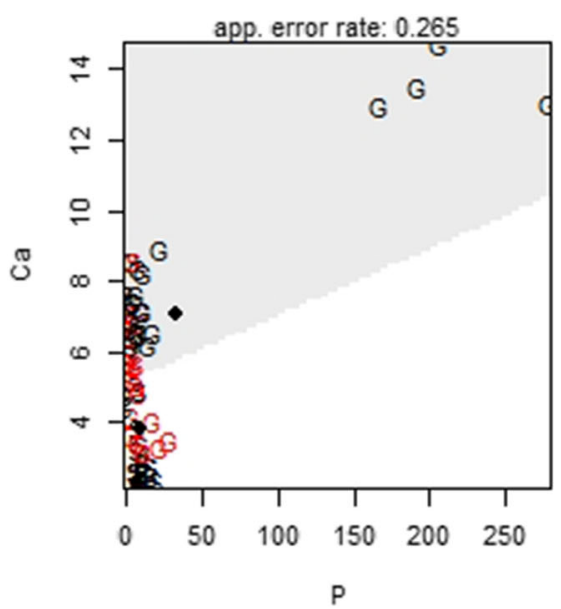

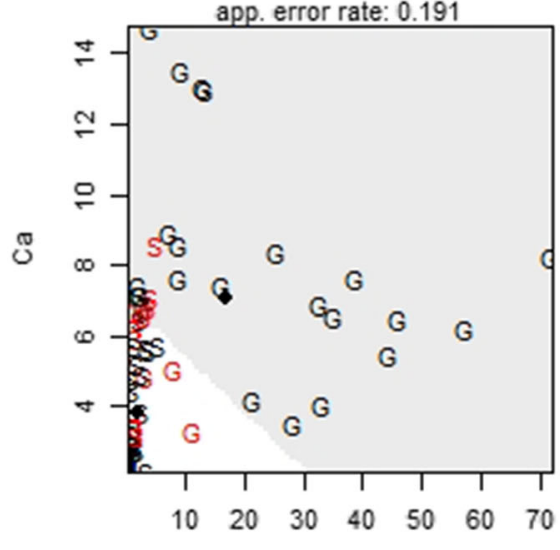

$\mathrm{Zn}$

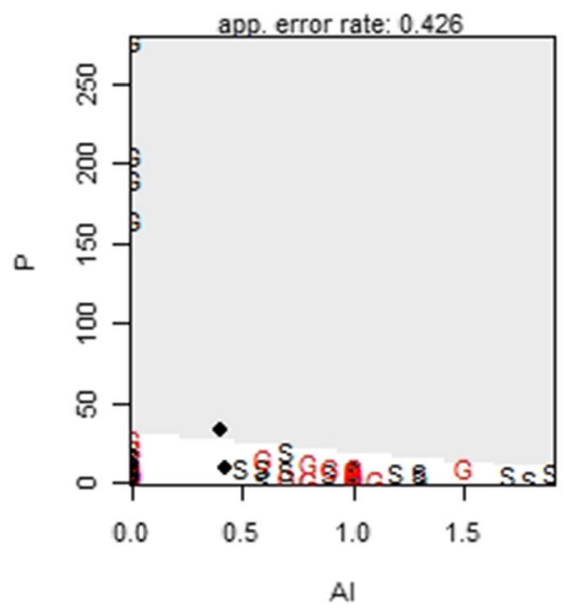

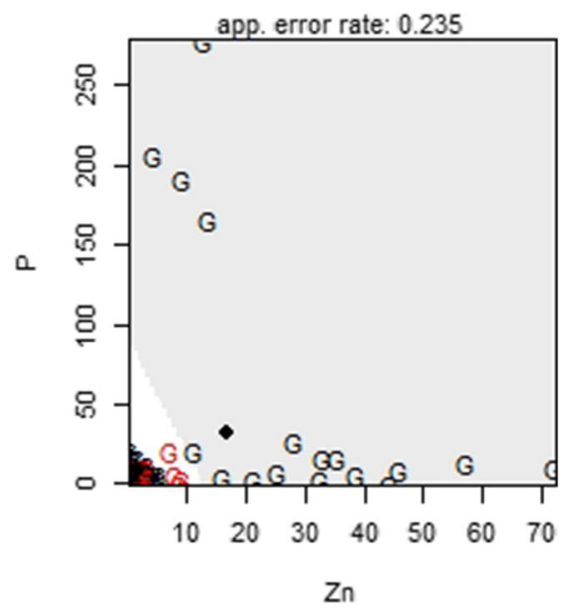

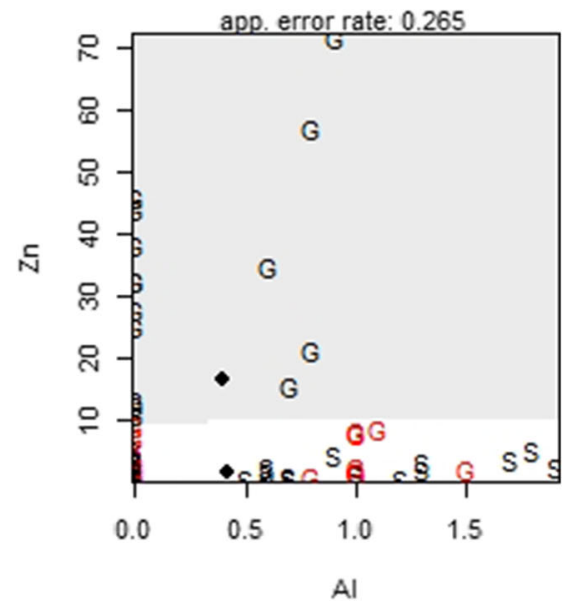

Fig. 5 Two-dimensional partitions analysis of soil properties with highest linear discriminant partition score for each type of deposit. Classification borders are displayed, and apparent error rates provided for every combination of properties. G, gravel deposits; S, sandy deposits.
Characters in red represent sets of soil samples that correspond to $G$ wrongly classified as sand deposits and sets of soil samples that corresponds to $\mathrm{S}$ wrongly classified as gravel increased with time under the influence of biological factors. Therefore, the influence of biological factors on pedogenic development of the studied Technosols can be similar to that of natural soils (Jangorzo et al. 2015). However, the lack of significant differences in soil properties at different sampling depths can be explained by the mixing pattern of the material, which initially creates a homogeneous profile. Nevertheless, it is possible that a deeper sampling can reveal differences, as the subsurface is expected to be less influenced by soil forming processes (Huot et al. 2015).

No significant differences were found for changes in soil physical properties of both types of deposits over the different time periods since dredged sediment deposition. The extreme values observed for certain soil chemical properties may limit the power of the chronosequence approach used for this study to elucidate significant trends on Technosol developments. In addition, the lack of significant changes in soil-physical properties could be explained by the relatively short time of establishment of the plots, which could indicate that the time period was too short for environmental conditions and climate to have significantly influenced the physical properties.

The analysis of bulk density in the context of vegetation establishment is crucial given that high bulk densities might limit rooting depth. Severely compacted soils (bulk density $>1.7 \mathrm{~g}$ / $\mathrm{cm}^{3}$ ) cannot hold enough plant-available water to sustain plants during dry seasons (Maiti and Ghose 2005). In addition, it is expected that while reclaiming mining land, the soil becomes compacted with the subsequent overall decrease in groundwater recharge through precipitation (Ahirwal and Maiti 2016). For the study site, the bulk density values cannot be considered as those of severely compacted soils, although the gravel deposits had higher bulk densities than the sandy deposits (Table 3). Furthermore, the field capacity for both deposits was below $20 \%$. On the same lines, very rapid infiltration was observed for both types of deposits, as well as high saturated hydraulic conductivities. Even though gravel is considered an inert 


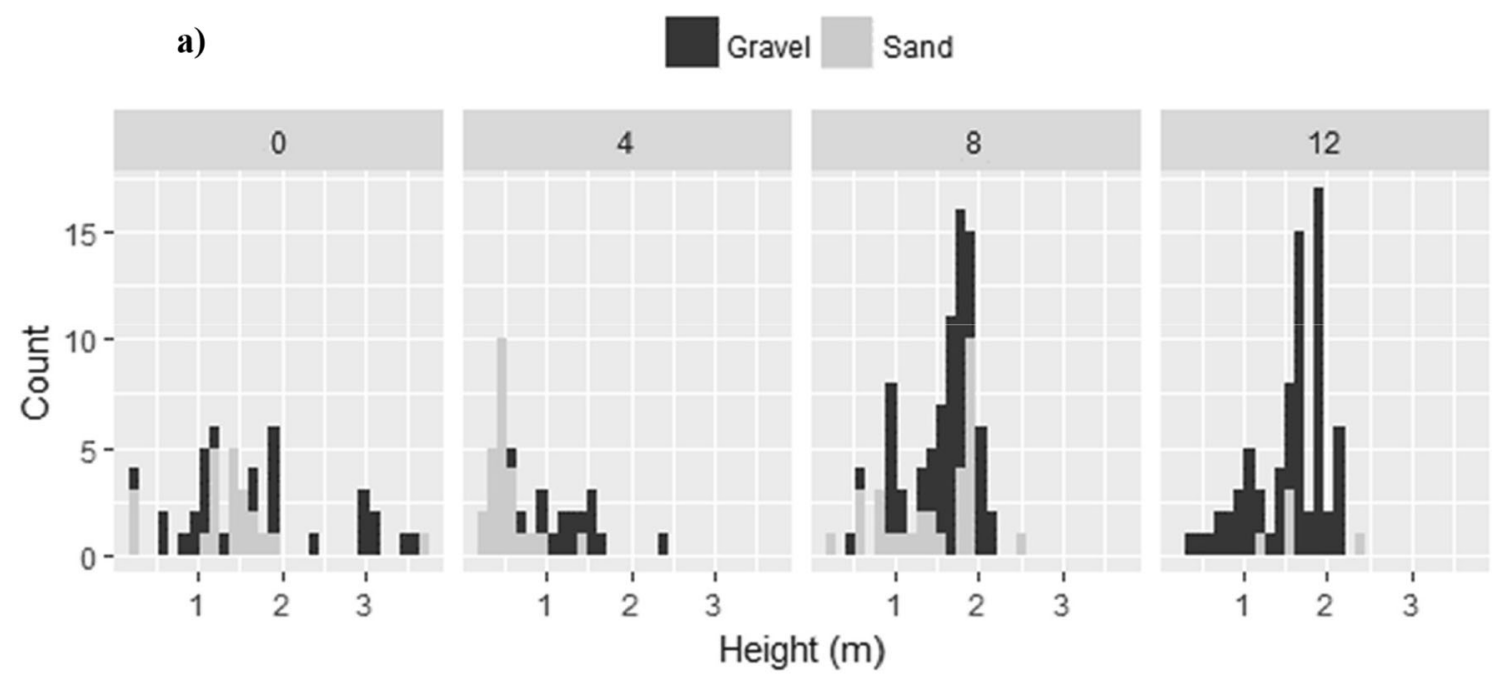

b)

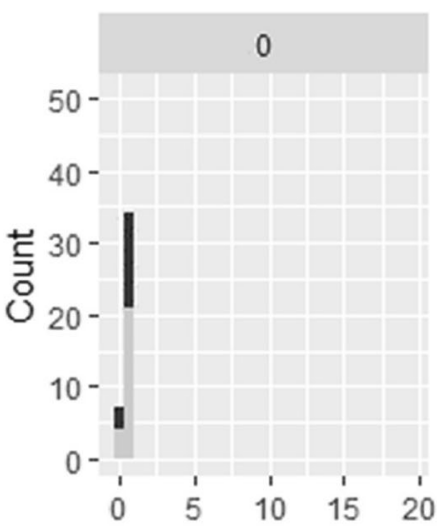

Height (m)

8

Gravel

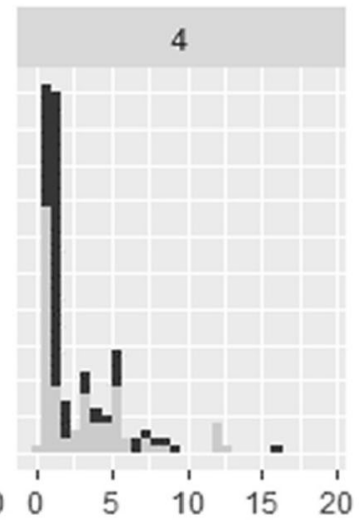

\section{Sand}
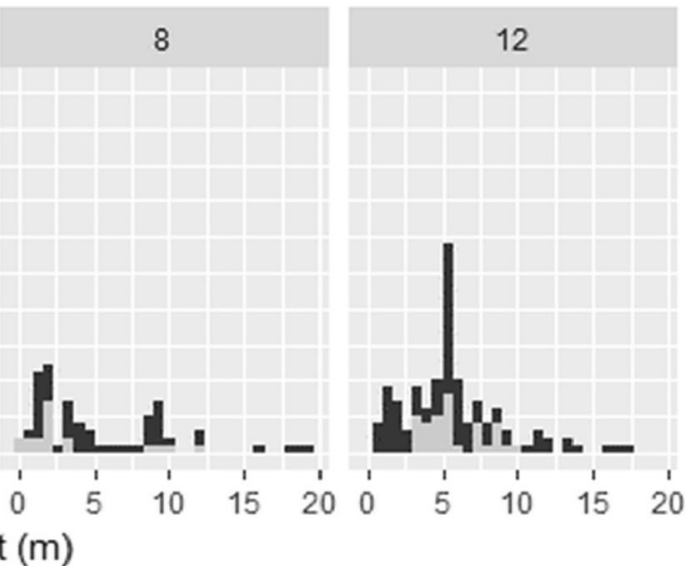

Fig. 6 Abundance profiles of a trees and $\mathbf{b}$ shrubs calculated for different years since dredged sediment deposition $(0,4,8$, and 12 years) for gravel

component of a soil, it has a diluting effect on the amount of stored water and nutrients, affects infiltration and runoff rates, and introduces heterogeneity into soils (Rytter 2012).

A slight decrease in $\mathrm{pH}$ of the topsoil is a frequently observed process in Technosols forming from dredged sediment deposits (Huot et al. 2015). A moderately low pH was observed in both gravel and sandy deposits, while extremely low $\mathrm{pH}$ values that might cause metal toxicity to plants were not registered. The $\mathrm{pH}$ values of the gravel deposits were found to vary from neutral for samples corresponding to the non-revegetated area to low values for samples $>12$ years after deposition. The change in the $\mathrm{pH}$ can be explained by oxidation of the minerals and root growth. Roots typically change the $\mathrm{pH}$ of the rhizosphere by imbalances in uptake of cations and anions and by release of organic acids and chelating agents that alter the availability of some nutrients (Darrah et al. 2006). The predominance of an acid reaction has also been documented for technogenic surface formations of and sandy deposits. Total tree/shrub height was used as a structural variable to calculate the profiles

dredged dumping grounds in areas of placer gold mining in Russia (Shlyakhov and Osipov 2004).

During mining and reclamation activities, TOC is lost in various ways, i.e., through erosion of soil by water and wind, reduction of inputs due to lack of vegetation, heavy washing of soil by dredges. However, TOC plays a crucial role in vegetation growth and ecosystem development through an improved water-holding capacity, nutrient availability, and soil structure (Huot et al. 2015). For our study site, the levels of TOC were remarkably high. In addition, both types of deposits exhibited higher values of TOC 12 years after dredged sediment deposition. The high values might be attributable to the fact that the deposits were former bottoms of sedimentation basins (Shlyakhov and Osipov 2004). In addition, the higher values found for older deposits might be attributable to vegetation development in reclaimed sites, higher biomass production, and litter accumulation with time (Tetteh et al. 2015). 
Phosphorus levels in gravel deposits $>4$ years after dredged sediment deposition are lower than in gravel deposits with no vegetation cover. Previous studies conducted by Castellanos and Leon (2010) in the same research area show that $\mathrm{P}$ was the nutrient that limited the productivity of A. mangium used to reforest sand and gravel deposits (Castellanos and Leon 2010). Therefore, as a consequence of vegetation reestablishment, the $P$ concentration is reduced.

In dredged sediment deposits, metals and nutrients can enter the $\mathrm{O}$ and $\mathrm{A}$ horizons through dry and wet atmospheric depositions, stem flow, litterfall, and direct upward migration from the C horizon (Vandecasteele et al. 2009). Lindsay and Norvell (1978) mention values rated as highly sufficient for ecologically sustainable reclamation as being $4.5 \mathrm{mg} / \mathrm{kg} \mathrm{Fe}$, $1.0 \mathrm{mg} / \mathrm{kg} \mathrm{Mn}, 1 \mathrm{mg} / \mathrm{kg} \mathrm{Zn}$, and $0.4 \mathrm{mg} / \mathrm{kg} \mathrm{Cu}$. In $97 \%$ of the samples from the gravel deposits, $\mathrm{Zn}$ exceeded the concentration recommended by the above authors, while in contrast only $6 \%$ of the sandy deposit samples had $\mathrm{Zn}$ concentrations above the threshold. All samples taken from the gravel and sandy deposits showed levels of $\mathrm{Fe}, \mathrm{Mn}$, and $\mathrm{Cu}$ that exceeded the threshold recommended by the authors. Critical levels of $\mathrm{Mn}$ that can begin to affect the yield of sensitive species are > $65 \mathrm{mg} / \mathrm{kg} \mathrm{Mn}$ (Hazelton and Murphy 2007). For the gravel deposits, $52 \%$ of the samples had Mn contents above the critical level and $46 \%$ of the sandy deposits also showed Mn values above the critical level.

The analysis of vegetation development through the calculation of size distribution profiles of the trees and shrubs in four different areas with different time periods since revegetation provides evidence of a progressive vegetation growth. In the specific case of Technosols, a progressive plant community succession is only achievable through a favorable combination of soil type, soil physical regime, and type of initial plant community (Ciarkowska et al. 2016). The fact that trees and shrubs were taller in the gravel deposits suggests that the plant roots managed to proliferate into the nutrient-rich zones of these deposits. This can be explained by the high nutrient content of the $<2-\mathrm{mm}$ fraction of the gravel deposits. Plant growth, in spite of the observed uneven distribution of the $<2$ $\mathrm{mm}$ nutrient-rich fraction within the deposit layers, suggests that plants can respond morphologically to heterogeneity in nutrient availability of these deposits by preferentially growing roots in nutrient-rich zones or by shifting growth allocation to or from roots (Robinson 2005). Therefore, changes in root architecture can be mediating adaptation of the plants to these deposits (López-Bucio et al. 2003).

The lack of soil physicochemical properties required for plant growth in some areas of the Technosols can be compensated for through the application of amendments such as green manure or compost (Vergnes et al. 2017). In acidic areas with low concentrations of exchangeable cations, liming or especially wood ash application would be a suitable strategy due to their neutralizing capacity and availability in most households in the area (Neina et al. 2017). However, it is difficult to overcome limiting factors such as soil texture, stoniness or poor structure. Limiting factors for vegetation establishment in gravel and sandy deposits are the lower P contents and exchangeable cations observed in the older deposits, and the high $\mathrm{Fe}, \mathrm{Mn}, \mathrm{Zn}$, and $\mathrm{Al}$ contents, low water holding capacity and poor structural stability. Therefore, a careful selection of the plant species to be planted is required. For example, the use of legumes can increase soil-N content, increase TOC, and also improve soil porosity and structure ( $\mathrm{Li}$ et al. 2016). In addition, grasses characterized by fast growth can also help to stabilize the deposits and cover the land, and therefore can be used as a suitable initial cover for the barren deposits (Fullen et al. 2006). Vegetation succession will change the dominant plant cover of recently formed deposits from grasses to trees and shrubs, which will likely improve the structure of the dredged sediment deposits through root binding (Santini and Fey 2016). Thus, exclusively planting fastgrowing trees may not be as beneficial as mixed stands (Neina et al. 2017).

\section{Conclusions}

The Technosols developed from dredged sediment deposits undergo processes similar to those occurring in natural materials such as mineral transformations, changes in redox conditions, organic matter accumulation at the surface, and a relatively rapid differentiation of horizons. In addition, the studied Technosols show an unusually high rate of pedogenic processes with strong changes at very early stages of formation. These changes can be explained by the technology used for mining, the deposition of material during cumulative events across time, and disturbances after deposition that lead to very heterogeneous technogenic materials. Therefore, the extreme values observed for some soil chemical properties may limit the power of the chronosequence approach used for this study to elucidate significant trends on Technosol developments.

The particle size distribution has a significant effect on the pedogenesis of the studied Technosols, as gravel and sand deposits originated from the same sections of the river and subject to similar processes of removal of finer fractions could undergo pedogenic processes at different rates and with distinct characteristics. The pedogenic processes in gravel deposits occur faster than in sandy deposits. Based on the analysis of size distribution of tree and shrub communities, gravel deposits offer more favorable conditions for plant growth than sandy deposits. Sandy deposits are likely to have a polycyclic evolution at slower rates and may acidify, preventing vegetation development and slowing down pedogenic processes 
resulting from biological factors. Biological activity of mesofauna observed in sandy deposits suggests that the colonization by organisms could drive a new phase of development.

The farmers living in the study area face the challenge of identifying suitable areas and management strategies for successful cropping. Limiting factors for cropping in gravel and sandy deposits are the low P contents and exchangeable cations observed in the older deposits, and the high $\mathrm{Fe}, \mathrm{Mn}, \mathrm{Zn}$, and $\mathrm{Al}$ contents, low water holding capacity, and poor structural stability. Therefore, a careful selection of the species to be planted is required. For crop production, gravel as well as sandy deposit areas can be used, but organic amendments, such as organic matter or lime would be required for satisfactory establishment and growth of cultivated plants. Their establishment and growth can be supported through an initial coverage with natural topsoil. Such an intervention would pay off most probably only with high-value cash crops. The fact that sand and gravel deposits have remarkably different properties implies that for crop establishment they should be managed differently. Consequently, surveys are required to characterize the chemical and physical properties of the deposits to develop the best suited management strategies for agricultural use and reforestation. Furthermore, before the cultivation of food crops the levels of toxic elements should be assessed to ensure that crops growing in deposit areas do not pose a threat to human or livestock health.

Acknowledgments This work was sponsored by the Foundation fiat panis, the company Mineros S.A., the German Academic Exchange Service (DAAD) and the Center for Development Research (ZEF) at the University of Bonn. The authors thank the staff of Mineros S.A. for supporting the data collection for this research. The authors thank the reviewers for their detailed comments and suggestions that greatly enriched our discussion.

Funding Information Open Access funding provided by Projekt DEAL.

Open Access This article is licensed under a Creative Commons Attribution 4.0 International License, which permits use, sharing, adaptation, distribution and reproduction in any medium or format, as long as you give appropriate credit to the original author(s) and the source, provide a link to the Creative Commons licence, and indicate if changes were made. The images or other third party material in this article are included in the article's Creative Commons licence, unless indicated otherwise in a credit line to the material. If material is not included in the article's Creative Commons licence and your intended use is not permitted by statutory regulation or exceeds the permitted use, you will need to obtain permission directly from the copyright holder. To view a copy of this licence, visit http://creativecommons.org/licenses/by/4.0/.

\section{References}

Ahirwal J, Maiti SK (2016) Assessment of soil properties of different land uses generated due to surface coal mining activities in tropical Sal (Shorea robusta) forest, India. CATENA 140:155-163
Anderson MJ (2001) A new method for non-parametric multivariate analysis of variance. Aust Ecol 26(1):32-46

Castellanos J, Leon J (2010) Litterfall and nutrient dynamics in Acacia mangium (Mimosaceae) forest plantations of Antioquia, Colombia. Acta Biológica Colombiana 15:289-308

Ciarkowska K, Gargiulo L, Mele G (2016) Natural restoration of soils on mine heaps with similar technogenic parent material: a case study of long-term soil evolution in Silesian-Krakow upland Poland. Geoderma 261:141-150

Clarke KR (1993) Non-parametric multivariate analyses of changes in community structure. Aust Ecol 181:117-143

Clarke KR, Ainsworth M (1993) A method of linking multivariate community. Mar Ecol Prog Ser 92:205-219

Cooke JA, Johnson MS (2002) Ecological restoration of land with particular reference to the mining of metals and industrial minerals. A review of theory and practice. Environ Rev 10:41-71

Darrah PR, Jones DL, Kirk GJD, Roose T (2006) Modelling the rhizosphere: a review of methods for 'upscaling'to the whole-plant scale. Eur J Soil Sci 57(1):13-25

De Cáceres M, Legendre P, He F (2013) Dissimilarity measurements and the size structure of ecological communities. Methods Ecol Evol 4(12):1167-1177

Fullen MA, Booth CA, Brandsma RT (2006) Long-term effects of grass ley set-aside on erosion rates and soil organic matter on sandy soils in East Shropshire, UK. Soil Tillage Res 89:122-128

González Molina JM, Piqué Nicolau M, Vericat Grau P (2006) Manual de ordenación por rodales: gestión multifuncional de los espacios forestales. 2nd edition. Organismo autónomo Parques Nacionales, Ministerio de Medio Ambiente y Medio Rural y Marino

Hazelton P, Murphy B (2007) Interpreting soil test results: what do all those numbers mean. CSIRO Publishing, Collingwood

Huberty CJ, Morris JD (1989) Multivariate analysis versus multiple univariate analyses. Psychol Bull 105:302

Huot H, Simonnot M, Morel JL (2015) Pedogenic trends in soils formed in technogenic parent materials. Soil Sci 180(4/5):182-192

IUSS Working Group (2015) World reference base for soil resources 2014 international soil classification system for naming soils and creating legends for soil maps. World soil resources reports no. 106. FAO, Rome

Jahn R, Blume HP, Asio VB, Spaargaren O, Schad P (2006) Guidelines for soil description, 4th edition. ISRIC - World Soil Information, Internationaal Bodemreferentie en Informatie Centrum. ICSU World Data Centre for Soils. FAO, Rome. Available at: https:// edepot.wur.n1/27622

Jangorzo NS, Watteau F, Hajos D, Schwartz C (2015) Nondestructive monitoring of the effect of biological activity on the pedogenesis of a Technosol. J Soils Sediments 15:1705-1715

Jangorzo NS, Watteau F, Schwartz C (2013) Evolution of the pore structure of constructed Technosols during early pedogenesis quantified by image analysis. Geoderma 207-208:180-192

Li Q, Yu P, Li G, Zhou D (2016) Grass-legume ratio can change soil carbon and nitrogen storage in a temperate steppe grassland. Soil Tillage Res 157:23-31

Lindbo DL, Stolt MH, Vepraskas MJ (2010) Redoximorphic features. In Stoops G, Marcelino V Mees, F (eds) Interpretation of micromorphological features of soils and regoliths. Elsevier, Oxford, pp 129 147

Lindsay WL, Norvell WA (1978) Development of a DTPA soil test for zinc, iron, manganese, and copper 1. Soil Sci Soc Am J 42(3):421428

Loaiza JC, Stoops G, Poch R, Casamitjana M (Eds) (2015) Manual de micromorfología de suelos y técnicas complementarias. Fondo Editorial Pascual Bravo, Medellín

López-Bucio J, Cruz-Ramírez A, Herrera-Estrella L (2003) The role of nutrient availability in regulating root architecture. Curr Opin Plant Biol 6:280-287 
Maiti SK, Ghose MK (2005) Ecological restoration of acidic coalmine overburden dumps- an Indian case study. Land Contam Reclam 13: 361-369

McArdle BH, Anderson MJ (2001) Fitting multivariate models to community data: a comment on distance-based redundancy analysis. Ecology 82(1):290-297

Munsell Color (Firm) (2010) Munsell soil color charts: with genuine Munsell color chips. Munsell Color, Grand Rapids

Nair PKR (1993) An introduction to agroforestry. Kluwer Academic Publishers, Dordrecht, 499 pp

Neina D, Buerkert A, Joergensen RG (2017) Effects of land use on microbial indices in tantalite mine soils, western Rwanda. Land Degrad Dev 28:181-188

Oksanen J, Guillaume F, Friendly M, Kindt R, Legendre P, McGlinn D, Minchin P, O’Hara R, Simpson G, Solymos P, Stevens H, Szoecs E, Wagner H (2017) Vegan: community ecology package. https:// www.CRANR-projectorg/package=vegan

Philippi TE, Dixon PM, Taylor BE (1998) Detecting trends in species composition. Ecol Appl 8:300-308

Richards L, Weaver L (1944) Moisture retention by some irrigated soils as related to soil moisture tension. J Agric Res 69:215-235

Robinson D (2005) Integrated root responses to variations in nutrient supply. In: BassiriRad H (ed) Nutrient acquisition by plants. Springer-Verlag, Berlin/Heidelberg

Rytter RM (2012) Stone and gravel contents of arable soils influence estimates of $\mathrm{C}$ and $\mathrm{N}$ stocks. CATENA 95:153-159

Santini TC, Fey MV (2016) Assessment of Technosol formation and in situ remediation in capped alkaline tailings. CATENA 136:17-29

Séré G, Schwartz C, Ouvrard S, Renat J-C, Watteau F, Villemin G, Morel JL (2010) Early pedogenic evolution of constructed Technosols. J Soils Sediments 10:1246-1254

Shlyakhov S, Osipov S (2004) Technogenic surface formations in the areas of placer gold mining. Eurasian Soil Sci 37:1106-1114

Soil Science Division Staff (2017) Soil survey manual USDA handbook 18. Washington, DC https://wwwnrcsusdagov/wps/portal/nrcs/ detailfull/soils/ref/?cid=nrcs142p2_054262.
Tetteh EN, Logah V, Twum-Ampofo K, Partey ST (2015) Effect of duration of reclamation on soil quality indicators of a surface-mined acid forest oxisol in South-Western Ghana. West Afr J App Ecol 23(2):63-72

UNODC (2016) Explotación de oro de aluvión. Evidencias a partir de percepción remota, Bogota https://www.unodc.org/documents/ colombia/2016/junio/Explotacion_de_Oro_de_Aluvion.pdf

Uzarowicz Ł, Zagórski Z, Mendak E, Bartmiński P, Szara E, Kondras M, Oktaba L, Turek A, Rogoziński R (2017) Technogenic soils (Technosols) developed from fly ash and bottom ash from thermal power stations combusting bituminous coal and lignite. Part I. Properties, classification, and indicators of early pedogenesis. CATENA 157:75-89

Vandecasteele B, Quataert P, Genouw G, Lettens S, Tack F (2009) Effects of willow stands on heavy metal concentrations and top soil properties of infrastructure spoil landfills and dredged sediment-derived sites. Sci Total Environ 407:5289-5297

Venables WN, Ripley BD (2002) Modern applied statistics with S. Fourth Springer, New York

Vergnes A, Blouin M, Muratet A, Lerch TZ, Mendez-Millan M, RouelleCastrec M, Dubs F (2017) Initial conditions during Technosol implementation shape earthworms and ants diversity. Landsc Urban Plan 159:32-41

Wahsha M, Al-Rshaidat MMD (2014) Potentially harmful elements in abandoned mine waste. In: Bini C, Bech J (eds) PHEs, environment and human health. Springer Netherlands, Dordrecht, pp 199-220

Weihs C, Ligges U, Luebke K, Raabe N (2005) klaR analyzing German business cycles. In: Baier D, Decker R, Schmidt-Thieme L (eds) Data analysis and decision support. Springer-Verlag, Berlin, pp 335-343

Yoder R (1936) A direct method of aggregate analysis of soils and a study of the physical nature of erosion losses. Agron J 28:337-351

Publisher's note Springer Nature remains neutral with regard to jurisdictional claims in published maps and institutional affiliations. 